\title{
Emergent Concepts from the Intestinal Guanylyl Cyclase C Pathway
}

\author{
Mehboob Ali and Giovanni M. Pitari \\ Division of Clinical Pharmacology, \\ Thomas Jefferson University, Philadelphia, PA,
}

USA

\section{Introduction}

Cancer is one of the world's top killers accounting for 7.4 million deaths, or $13 \%$ of all deaths (World Health Organization [WHO], 2011). Colorectal cancer is the third most common and deadly cancer worldwide (Jemal et al., 2011). An unequal geographic distribution of the disease burden exists, with less developed areas of the world exhibiting the lowest incidence and mortality (Pitari et al., 2003). In contrast, populations dwelling in western countries are at increased risk to develop and die of colorectal cancer. In the US, 141,210 new cases are estimated to be diagnosed in 2011 and 49,380 patients are expected to die for this disease, representing an intolerable socio-economical toll (Siegel et al., 2011).

Promises derive from substantial advancements in early detection and prevention strategies, which have contributed to reduce colorectal cancer incidence and mortality rates in recent years (Siegel et al., 2011). However, new chemotherapeutic approaches have not emerged and terminal clinical stages of the disease remain incurable. Specifically, invasion and metastatic disease progression, traditionally unnameable to surgical resection, are largely refractory to pharmacological therapy. About $90 \%$ of patients with distant metastasis die of the disease within 5 years from diagnosis (Siegel et al., 2011). Moreover, racial and educational health-disparities exist in which minorities and less educated individuals of the affected population exhibit the worst clinical prognosis and the highest mortality, in part reflecting their more advanced stages at diagnosis compared to other patient segments (Siegel et al., 2011). Together, these considerations underscore the enormous impact that therapeutic target discovery might have on western societies, especially if they would translate into innovative, curative pharmacological approaches that will prolong the survival of patients with colorectal cancer.

Crucial systems regulating the intestinal crypt-villus axis are also important determinants of the carcinogenetic process (Aoki et al., 2003; Fodde et al., 2001; Korinek et al., 1998). Among these, the signalling pathway orchestrated by the surface receptor guanylyl cyclase C (GCC) has recently emerged as both an integral component of intestinal mucosa homeostasis and a negative regulator of the malignant cell phenotype. GCC, expressed in the epithelial layer of the gastrointestinal wall, and its endogenous ligands guanylin and uroguanylin control fluid balance and renewal crypt dynamics by operating sophisticated biochemical circuits in both the small and large intestine. Intriguingly, a bacterial mimicry of endogenous 
hormones exists, the E. coli heat-stable enterotoxin (ST), which may confer both harmful (watery diarrhea) and beneficial (colorectal cancer resistance) effects to exposed individuals (Lucas et al., 2000; Pitari et al., 2001). In this model, the uneven epidemiological distribution of colon cancer incidence across different geographic areas of the world reflect, in part, inverse differences in the prevalence of enterotoxigenic E. coli infections (Pitari et al., 2003). Moreover, an unexplained mutation early in colorectal tumorigenesis leads to the loss of guanylin and uroguanylin expression, producing a dormant GCC pathway in neoplastic cells (Fig. 1) (Pitari et al., 2007).

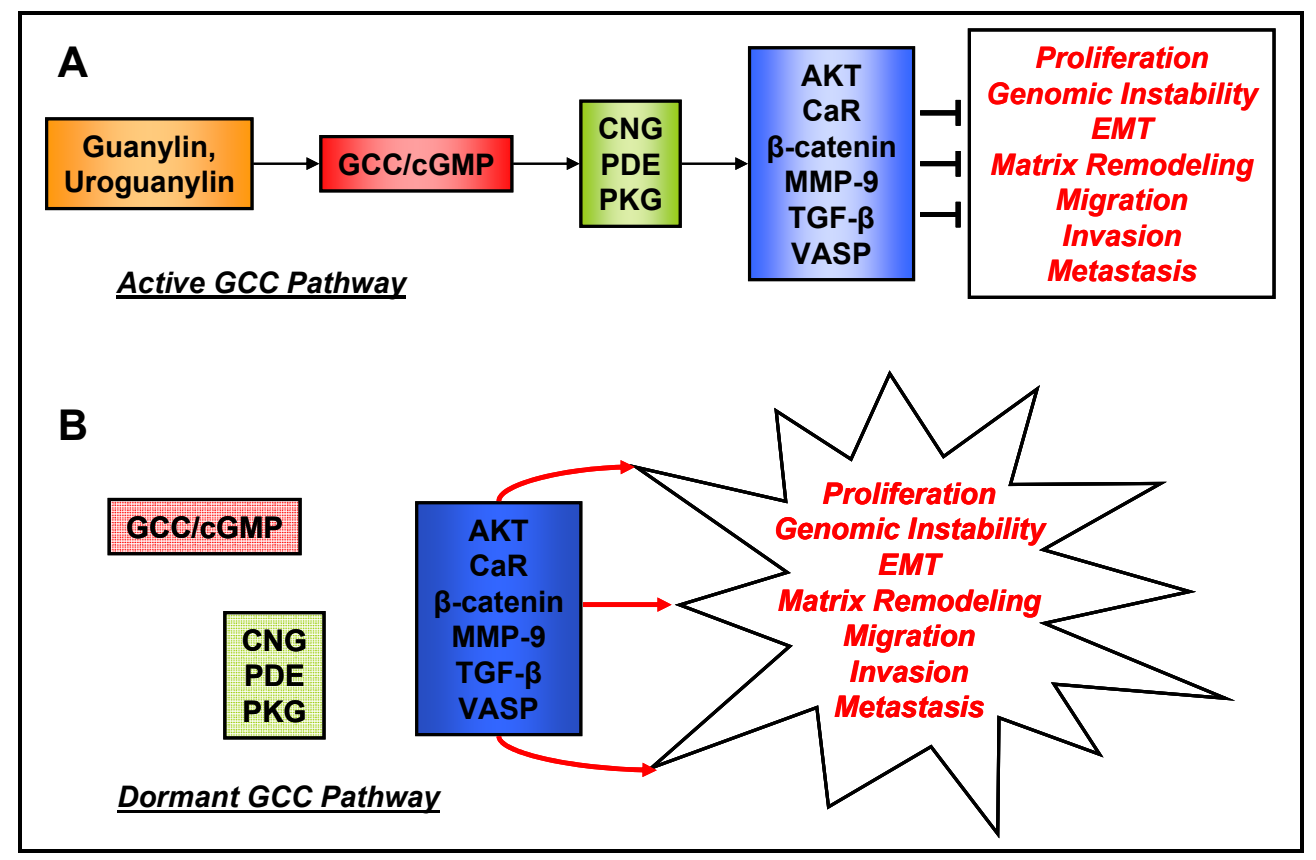

Fig. 1. Significance of the dormant guanylyl cyclase C (GCC) pathway for colorectal carcinogenesis.

Selected GCC signalling components with reported impact on tumorigenesis are depicted. A) In normal intestinal physiology, the GCC pathway is constitutively activated by paracrine hormonal regulation with the endogenous GCC agonists guanylin and uroguanylin. The active GCC pathway promotes signalling by proximal cGMP effectors cyclic nucleotide-gated channel (CNG), phosphodiesterases (PDE) and protein kinase G (PKG) that, in turn, affect the function of key distal effectors, including the v-akt murine thymoma viral oncogene homolog (AKT), $\mathrm{Ca}^{2+}$-sensing receptor $(\mathrm{CaR}), \beta$-catenin, matrix metalloproteinase 9 (MMP-9), transforming growth factor $\beta$ (TGF- $\beta$ ), and vasodilatorstimulated phosphoprotein (VASP). As a result, tumorigenic forces are restrained and normal intestinal mucosa homeostasis is maintained. B) During neoplastic transformation the GCC pathway becomes dormant, principally because of the loss of endogenous hormone expression. Loss of signalling between GCC and the proximal cGMP effectors deregulates the distal components of the pathway, thereby producing an oncogenic system favouring colorectal cancer progression and metastasis. EMT, epithelial-mesenchymal transition. 
This chapter will details the consequences at the functional and cellular level of the silenced GCC signalling for colorectal tumor formation and progression. Key molecular effectors comprising the GCC pathway with high clinical translational significance will be presented and their potential impacts for both diagnostic and therapeutic advances discussed.

\section{GCC and the intestinal crypt-villus axis}

GCC is a member of membrane-bound guanylyl cyclases (GCA to GCG), enzymes which catalyze the formation of cyclic guanosine monophosphate (cGMP) from GTP. Although they exhibit unique physicochemical and antigenic properties, particulate guanylyl cyclases are homodimeric transmembrane domain proteins sharing conserved cytoplasmic portions with tyrosine kinase-like and cyclase catalytic domains (Lucas et al., 2000). The amino acid sequence of GCC considerably diverges from the other isoforms in the extracellular domain, which represents the ligand binding domain for the E. coli heat-stable enterotoxin ST and the endogenous peptides guanylin and uroguanylin (Lucas et al., 2000). Beyond selected dopaminergic neurons in the central nervous system (Gong et al., 2011), in mammals GCC expression is principally restricted to brush-border membranes of epithelial cells lining the intestinal inner surface from the duodenum to the rectum, uniformly distributed along the crypt-villus axis (Lucas et al., 2000). This unique anatomical distribution subserves the functional role of GCC as a critical regulator of the intestinal mucosa homeostasis. In particular, the signalling pathway regulated by GCC and its second messenger cGMP contributes to the control of epithelial self-renewal and maturation dynamics underlying the integrity of the crypt-villus axis (Pitari et al., 2007).

\subsection{The GCC pathway}

Modulation of intracellular cGMP concentrations represents the fundamental event of a variety of signal transduction circuits shaping cellular behaviour. Synthesis (by guanylyl cyclases) and breakdown (by phosphodiesterases) are recognized as the major mechanisms defining cGMP levels in tissues. In intestinal epithelial cells, GCC is the principle source of cGMP (Lucas et al., 2000). GCC activity defines the type, intensity and duration of biological responses mediated by cGMP through unique physical, spatial and temporal dynamics at intestinal mucosal surfaces. The most important modality to regulate GCC activity is by ligand binding to its extracellular domain, which induces an intramolecular conformational change that is transmitted down to the cytoplasmic C-terminus catalytic domain. In this way, cellular cGMP levels can be raised numerous folds over basal states (Lucas et al., 2000; Schulz et al., 1989). Furthermore, the three ligand peptides know to induce GCC activation in mammalian cells exhibit different affinities and potencies for GCC, resulting in different patterns of cGMP concentrations/effects. The exogenous ligand ST, produced by E. coli and responsible for life-threatening diarrhoeagenic syndromes, is the most potent GCC agonist and consists of 18 amino acids with three intrachain disulfide bonds (Guarino et al., 1989). In contrast the endogenous paracrine hormones, guanylin and uroguanylin, are 15-16 amino acid long with two intrachain disulfide bonds and uneven tissue distributions and physicochemical characteristics. Thus, while uroguanylin is a more potent $(\sim 100$ fold $)$ and abundant GCC agonist at acidic $\mathrm{pH}$ of proximal intestinal tracts, guanylin is more potent ( $\sim$ fold) as a GCC agonist at basic pH and is highly expressed in the colon and rectum (Forte, 1999; Hamra et al., 1997). Finally, elegant spatio-temporal constrains along the crypt-villus axis 
represent additional determinants of cGMP signalling by GCC. At the tissue level, maximal GCC activity and the dependant cGMP functions are imposed at the epithelial crypt/villus interface by increased GCC ligand expression (Cohen et al., 1995; Whitaker et al., 1997). In addition at the cellular level, compartmentalization of GCC-ligand interactions at luminal membrane borders establishes an increasing baso-apical cGMP gradient, wherein highest nucleotide concentrations are ensured at microvillus cell domains (Lucas et al., 2000).

Beyond GCC activation, the functional consequences of cGMP rises in intestinal epithelial cells reflect the specific expression and compartmentalization of downstream target molecules. Two evolutionarily distinct allosteric binding sites for cGMP exist in eukaryotic cells: one is present in cGMP- (PKG) and cAMP- (PKA) dependent protein kinases and in the cyclic nucleotide gated (CNG) cation channels, while the other is expressed in cGMPregulated phoshodiesterases (PDEs). These proteins represent the intracellular receptors for cGMP and permit the selective transmission of information in a cell-(and subcellular-) specific manner. PKGs are Ser/Thr protein kinases comprising the soluble type I, widely distributed across tissues and including the isoforms Ia and I $\beta$, and the particulate type II, mainly expressed in the intestine (Pfeifer et al., 1999). PKA is a tetrameric kinase preferentially activated by cAMP (Chao et al., 1994). CNG channels are heterotetrameric proteins of $\alpha$ - and $\beta$-subunits, which mediate membrane $\mathrm{Na}^{+}$and $\mathrm{Ca}^{2+}$ influx by cGMP in intestine as well as different other tissues (Bielet al., 1999). Further, cGMP-regulated PDEs (eg, PDE2, PDE5) are hydrolytic enzymes specialized in cleaving the cyclic nucleotide phosphodiester bond, thereby terminating correspondent biological activities (Corbin \& Francis, 1999; Francis et al., 2011). Cyclic GMP binding to the consensus site of these intracellular targets results in regulation of important downstream effectors which control specific biochemical networks and cellular functions. Molecules distal to cGMP with paramount significance for intestinal cell biology include ions, ion channels, cytoskeleton regulators and enzymes. For instance, cGMP binding to two allosteric sites present at the amino-terminal region of PKG II fully activates the enzyme and induces phosphorylation and opening of the cystic fibrosis transmembrane conductance regulator (CFTR), a pivotal mechanism underlying control of intestinal fluid homeostasis (Pfeifer et al., 1999). For an in depth discussion on the regulation of the various biochemical cGMP-dependent targets, such as the CFTR channel, the reader is referred to other comprehensive reviews (Browning et al., 2010; Lucas et al., 2000; Steinbrecher \& Cohen, 2011). Here, the focus will be on those molecular elements of the GCC and cGMP pathway that affect the epithelial cell phenotype, including its proliferative, morphogenetic and migratory attributes that greatly influence the crypt-villus homeostasis and the process of neoplastic transformation.

\subsection{Regulation of the intestinal epithelial cell phenotype}

The human intestinal mucosa is characterized by minute tubular invaginations called crypts, of maximal length in large intestinal tracts. In addition, the small intestinal mucosa exhibits lumenal protrusions of multi- (villi) and sub-cellular (microvilli) dimensions devoted to digestive activities. As a result, the inner intestinal surface is enormously expanded to optimally serve fundamental processes, from food processing and absorption to pathogen protection and immune system control (Montgomery et al., 1999). In this context, the complexity of those processes, constantly exposing the organism to potentially harmful external factors, is reflected by the sophisticated functional organization adopted by the columnar monolayer of epithelial cells lining the intestine. First, a self-renewal epithelial 
ability is conferred by multipotent stem cells located at crypt bottoms, ensuring weekly cycles of cellular replacement to eliminate damaged or aging cells worn out by the demanding intestinal functions (Potten \& Loeffler, 1990). Also, intriguing maturation dynamics are operating that turn proliferating progenitor cells into differentiated, cell cyclearrested epithelial cells with specialized functions, mostly populating the upper crypt and villus areas. They include a) the enterocytes, absorptive cells with food digestive functions (Montgomery et al., 1999), b) goblet cells, mucus-producing cells with detergent activities (Koldovsky et al., 1995), c) enteroendocrine cells, hormone-secreting cells comprising an intestinal endocrine system (Koldovsky et al., 1995), and d) Paneth cells, which secrete antimicrobial peptides and growth factors and are uniquely located at crypt bases (Bry et al., 1994). Further, incompletely understood check-up mechanisms constantly detect genetic or epigenetic defects and direct epithelial cells to the appropriate maintenance (e.g., cell resistance), self-repair (e.g., DNA excision repair) or death (e.g., apoptosis, autophagy) program (Potten \& Loeffler, 1990). Finally, the spatio-temporal coordination of this variety of processes is ensured by the migratory nature of the epithelial monolayer that physically maps the proliferation-differentiation transition at crypt/villus (small intestine) or lower/upper crypt (colon) interfaces, and drives the shedding of senescent cells at mucosal tips (Montgomery et al., 1999).

The GCC signalling pathway represents one of the elaborate homeostatic mechanisms evolved to direct the integration of each component supporting the intestinal epithelial cell phenotype. Indeed, targeted deletion of guanylin expression induces expansion of the proliferating crypt compartment and accelerated cell migration in mouse colon, presumably as a consequence of reduced GCC activation and cGMP-dependent signalling (Steinbrecher et al., 2002). In agreement with this notion, elimination of GCC in mice produces hyperplastic colonic crypts, populated by a higher number of fast-cycling and fast-migrating progenitor cells, associated with impaired cell maturation and death dynamics, with fewer Paneth and goblet cells but increased apoptotic events ( $\mathrm{Li}$ et al., 2007a). Moreover, compound mice in which the expression of uroguanylin or GCC has been disrupted exhibit similar structural alterations in the crypt-villus axis, with loss of tight junction-mediated intestinal barrier function and increased mucosal permeability (Han et al., 2011). Of relevance, intestine-specific expression of GCC is under the control of the caudal homeobox gene $\mathrm{Cdx} 2$, a transcriptional factor regulating development and cell fate specification of intestinal epithelial cells (Park et al., 2000). The Cdx2 gene product binds a consensus site present in the GCC proximal promoter and stimulates GCC transcription in an intestinespecific fashion (Di Guglielmo et al., 2001). Thus, it is tempted to speculate that GCC expression and the dependant cGMP signalling are part of the universal developmental program supporting the integrity of the intestinal crypt-villus axis.

Molecular mechanisms underlying effects of the GCC pathway on the intestinal cell phenotype have only recently been investigated. In one paradigm, lumenal $\mathrm{Ca}^{2+}$ is the key distal mediator of GCC activity (Pitari et al., 2003, 2008). The role of dietary $\mathrm{Ca}^{2+}$ as antiproliferative agent and promoter of differentiation and cell death along the epithelial crypt-villus axis is well defined (Lipkin \& Newmark, 1995; Whitfield, 1992), and $\mathrm{Ca}^{2+}$ deficient diets induce larger proliferative compartments in mouse colonic crypts (Rozen et al., 1989). One key molecular target for antiproliferative effects by dietary $\mathrm{Ca}^{2+}$ is the $\mathrm{Ca}^{2+}$ sensing receptor $(\mathrm{CaR})$, a $\mathrm{G}$ protein-coupled receptor present at apical membranes of intestinal epithelial cells (Sheinin et al., 2000). Binding of $\mathrm{Ca}^{2+}$ to the $\mathrm{N}$-terminal extracellular 
domain of CaR initiates discreet intracellular events mediated by the second messengers inositol 1,4,5-triphosphate (IP3) and diacylglycerol (DAG), which result in mobilization of intracellular $\mathrm{Ca}^{2+}$ and protein kinase C (PKC) activation, respectively (Berridge et al., 2000; Gama et al., 1997; Rhee, 2001). Intriguingly, elimination of GCC expression in mice is associated with loss of $\mathrm{CaR}$ from enterocyte brush borders (Pitari et al., 2008). Moreover, expression of $\mathrm{CaR}$ and GCC ligands is maximal at upper-crypt areas (Chakrabarty et al., 2005; Cohen et al., 1995; Whitaker et al., 1997), where epithelial cells stop proliferation and enter the maturation program, suggesting that CaR activity may be subordinated to GCC signalling along the crypt-villus axis (Pitari et al., 2008). Further, lumenal $\mathrm{Ca}^{2+}(1-3 \mathrm{mM})$ triggering cell cycle arrest at colonic mid-crypts (Whitfield et al., 1995) opposes proproliferative $\beta$-catenin activity and favour p21- and p27-mediated differentiation (Chakrabarty et al., 2003, 2005), molecular effectors also regulated by cGMP signalling in the intestine (Lin et al., 2010; Liu et al., 2001). Thus, GCC signalling may promote the proliferation-differentiation transition of intestinal epithelial cells through $\mathrm{CaR}$ regulation (Pitari et al., 2008). This is important as CaR is also the receptor for other polyvalent cations (i.e., $\mathrm{Gd}^{3+}, \mathrm{Mg}^{2+}, \mathrm{Ni}^{2+}$ ) and polyamines (i.e., spermine, spermidine, putrescine) produced by commensal colonic bacteria (Hofer \& Brown, 2003), pointing to a crucial role of the GCC$\mathrm{CaR}$ pathway as regulator of a variety of antiproliferative signals in intestine (Pitari et al., 2008). In addition, lumenal $\mathrm{Ca}^{2+}$ may mediate intestinal GCC actions through CaRindependent mechanisms, including ionic currents by CNG channels (Biel et al., 1999; Pitari et al., 2003, 2008). Cyclic GMP-gated $\mathrm{Ca}^{2+}$ current through CNG is a major regulator of signal generation and transmission in excitable cells (Ames et al., 1999; Zufall et al., 1997). Of relevance, in colon cancer cells GCC signalling slows cell cycle progression, in part, by inducing cGMP-dependent CNG channel activation, intracellular $\mathrm{Ca}^{2+}$ influx and cytosolic $\mathrm{Ca}^{2+}$ rises (Pitari et al., 2003).

Another model proposes the v-akt murine thymoma viral oncogene homolog (AKT) as the master biological effector of the GCC pathway (Lin et al., 2010). AKT regulates survival and metabolic circuits in proliferating intestinal cells, and AKT over activation promotes crypt hyperplasia and tumorigenesis in mouse intestine (Sakatani et al., 2005). Importantly, elimination of GCC expression in mice results in hyperactivation of AKT signalling pathways, associated with expanded crypt compartments populated by glycolytic cells with accelerated $G_{1}-S$ cell cycle transition (Lin et al., 2010). Conversely, loss of GCC and cGMP signalling restricts the differentiated villus compartment and diminishes mitochondria-dependent oxidative metabolism in intestinal epithelial cells (Lin et al., 2010). Investigations employing genetic and pharmacologic manipulation of AKT confirmed that GCC signalling through cGMP control the proliferative cell metabolism by decreasing the function of AKT (Lin et al., 2010). Thus, AKT-dependent regulation of cell survival and glycolytic metabolism along the crypt-villus axis, at the basis of intestinal mucosa development and homeostasis, may be conditionally regulated by the activity of the GCC pathway, whose increasing crypt-villus gradient directly correlates with differentiation and oxidative phosphorylation.

\subsection{Regulation of epithelium-stroma interactions}

Beyond the epithelium, the intestinal wall also encompasses mesenchymal and a smooth muscle layers. The intestinal mesenchymal compartment comprises mucosal and submucosal layers of connective tissues, composed of both acellular (e.g., glycoproteins, 
hyaluronic acid, proteoglycans, collagen I and III) and cellular components (e.g., fibroblasts, myofibroblasts, leukocytes, endothelial cells). The basement membrane, a balanced mix of matrix components (e.g., nidogen, laminin, collagen IV, perlecan), physically separates the enterocytes from the underlying mesenchyme. The basement membrane and all the other mesenchymal components significantly contribute to the dynamic renewal of intestinal epithelial cells. Indeed, intestinal epithelium-stroma interactions contribute to maintain the crypt-villus homeostasis through direct cell-matrix and cell-cell contacts or paracrine signalling (Montgomery et al., 1999; Pinchuk et al., 2010). In contrast, corrupted epitheliumstroma interactions promote the initiation and progression of an array of intestinal pathologies (Kraus \& Arber, 2009; Suzuki et al., 2011).

Studies with targeted deletion of GCC in mice revealed striking morphogenetic alterations affecting the extra-epithelial layers of the intestine (Gibbons et al., 2009). Indeed, the intestinal wall of these mice is significantly enlarged compared to mice with normal GCC expression. The mesenchymal compartment exhibits hypertrophy as a result of both exaggerated activation of its cellular elements and increased deposition of its interstitial matrix components (Gibbons et al., 2009). In particular, an increased ratio of activated myofibroblasts over quiescent fibroblasts is present in mice with loss of GCC signalling, an alteration which contributes to the establishment of a reactive stromal environment characterized by overexpression of collagen I, tenascin C and matrix metalloproteinase 9 (MMP-9) (Gibbons et al., 2009). In part, these alterations appear to be the consequence of an increased interstitial activity of the profibrinogenic transforming growth factor $\beta$ (TGF- $\beta$ ), as GCC signalling through cGMP inhibits TGF- $\beta$ secretion and function in intestinal epithelial cells and opposes stromal remodelling underlying inflammatory processes (Gibbons et al., 2009). Further, intestinal smooth muscle layers of mice lacking GCC signalling exhibit hyperplasia and hypertrophy, which represent important contributors of the transmural gut enlargement in these animals (Gibbons et al., 2009). Thus, the GCC pathway operating in intestinal mucosal cells exerts strong developmental and functional influences on the underlying stroma, presumably by regulating discreet hormonal circuits supporting epithelial-mesenchymal crosstalk (Pitari et al., 2007). Given the established role of the intestinal mesenchyme in inflammation and tumorigenesis (Kraus \& Arber, 2009; Pinchuk et al., 2010; Suzuki et al., 2011), it is possible to speculate that dysregulation of GCC signalling in intestinal epithelial cells may favour the emergence of a reactive stromal environment promoting pathological processes.

\section{GCC and intestinal transformation}

Colorectal carcinogenesis comprises a pathological continuum turning pre-cancerous lesions into invasive malignant tumors. The process begins with single (epi)genetic mutations driven by carcinogenic insults that disrupt the physiological epithelial cell phenotype (Gryfe et al., 1997; van Engeland et al., 2011). As a result, the balance of migration, proliferation, differentiation and cell death along the colonic crypt-surface axis is perturbed and neoplastic cells with limitless replicative potential emerge. Remodelling of the surrounding stroma also participates to the promotion and progression of transformation, imposing cell non-autonomous drivers of tumorigenesis such us angiogenesis and inflammation (Kraus \& Arber, 2009; Suzuki et al., 2011). Ultimately, malignant cells lose their epithelial characteristics and acquire a mesenchymal phenotype that enables them to translocate and 
establish new colonies at distant sites, such as the liver, lung and peritoneum (Nicolson, 1988; Polyak \& Weinberg 2009; Suzuki et al., 2011).

The paracrine hormone hypothesis of colorectal cancer suggests that sporadic intestinal tumorigenesis is a process initiated by loss of endogenous GCC ligand expression, which induces a state of guanylinopenia and uroguanylinopenia (Pitari et al., 2007). Indeed, extensive studies have demonstrate that early in transformation intestinal epithelial cells acquire a mysterious mutation that renders pre-cancerous adenomatous lesions devoid of guanylin and uroguanylin (Birkenkamp-Demtroder et al., 2002; Cohen et al., 1998; Notterman et al., 2001; Steinbrecher et al., 2000). Those reports suggest that guanylin and uroguanylin, organized in a tail-to-tail configuration on human chromosome $1 \mathrm{p}$, are the most commonly lost gene products in colorectal cancer in both animals and humans, exhibiting mutational frequency rates comparable to that of APC. Conversely, GCC is retained in colorectal cancer cells, which often exhibit higher GCC expression levels compared to normal epithelial tissues (Schulz et al., 2006; Witek et al., 2005). Increased GCC in the context of reduced guanylin and uroguanylin expression probably reflects the common pharmacological paradigm of receptor upregulation following specific ligand deprivation. More importantly, dysregulation of GCC signalling with an intact, but silent (for failure of ligand-dependent activation), intracellular molecular pathway produces a dormant cGMP-regulated system, which might be pathognomonically associated with neoplastic disease progression (Pitari et al., 2007). In this model, colorectal carcinogenesis following paracrine GCC ligand insufficiency reflects the central role of GCC in coordinating processes maintaining epithelial cell homeostasis and the crypt-villus axis, including the proliferation-differentiation balance, migration, metabolic programming and mesenchymal development (Li et al., 2007a; Pitari et al., 2007).

\subsection{Regulation of the colon cancer cell phenotype}

Neoplastic cell transformation ensues from the stepwise accumulation of mutations that produce hyper functioning oncogenes and silenced tumor suppressors (Bishop \& Weinberg, 1996). Universally, the final combination of all the mutations and signalling deregulations occurring in cancers has similar functional consequences, the promotion of tumor cell growth and dissemination, and the evasion of host mechanisms of elimination (e.g., immuno-surveillance) (Hanahan \& Weinberg, 2000). In intestinal tumorigenesis, acquisition of these malignant traits resembles a pathological amplification of the crypt stem cell phenotype, which self-perpetuates through relentless rounds of cell proliferation and migration (Montgomery et al., 1999; Potten \& Loeffler, 1990). Conversely, invasive cancer cells progressively lose the morphology and metabolism of the differentiated epithelium, acquiring the ancestral functional plasticity of pluripotent stem cells. Indeed, overexpression of molecules (Wnt, $\beta$-catenin, Tcf) that support the crypt cell compartment (Gregorieff \& Clevers, 2005; Korinek et al., 1998), or disruption of gene products (the adenomatous polyposis coli gene APC, Smad, CDX-2) restricting it (Aoki et al., 2003; Fodde et al., 2001; Tang et al., 2005) promotes intestinal tumorigenesis in animal models. In close agreement with these observations, the majority of sporadic human colorectal cancers exhibits a perturbed APC signalling as the initial mutational event, which crystallizes crypt-like nuclear proliferative programs driven by the $\beta$-catenin/Tcf complex (Fodde et al., 2001). 
Since it regulates crypt compartments and the proliferation-differentiation balance along the crypt-villus axis (Li et al., 2007a; Pitari et al., 2007), dormancy of the GCC signalling pathway contributes to neoplastic transformation in the intestine ( $\mathrm{Li}$ et al., 2007a; Pitari et al., 2007). Indeed, the increased migration and proliferation induced by loss of GCC signalling in mucosal colonocytes (Li et al., 2007a) represents a significant oncogenic stress (Aoki et al., 2003; Spruck et al., 1999) that creates the pre-neoplastic intestinal crypt (Pitari et al., 2007). Accordingly, cell cycle progression and growth of human colon cancer cells, experimental mimicry of the GCC dormancy characterizing the human disease because they express GCC but not the endogenous ligands (Lucas et al., 2000; Pitari et al., 2001), are greatly impaired upon reactivation of GCC signalling with exogenous supplementation of its specific agonists (Pitari et al., 2001, 2003, 2005, 2008). Ligand-dependent GCC activation restores lost cGMP-regulated circuits and imposes cancer cytostasis by reducing nuclear DNA synthesis and the $G_{1} / S$ transition (Lin et al., 2010; Pitari et al., 2001). Antiproliferation by GCC, in part, is mediated by extracellular $\mathrm{Ca}^{2+}$ actions at cancer cell membrane surfaces, through its dependant effects on $\mathrm{CaR}$ activation and CNG channel-mediated $\mathrm{Ca}^{2+}$ influx (Pitari et al., 2003; Pitari et al., 2008). In addition, reactivation of GCC signalling through cGMP opposes the Wnt/ $\beta$-catenin/Tcf4 signalling axis, the regulator of the proliferative crypt phenotype and tumor promoter in intestine (Pinto \& Clevers 2005; Reya \& Clevers 2005; van Es et al., 2005), by directly inhibiting $\beta$-catenin stability (Liu et al., 2001; Thompson et al., 2000). Underscoring the significance of the dormant GCC pathway in colon cancer, elimination of GCC in mice significantly enhances intestinal tumor initiation and progression ( $\mathrm{Li}$ et al., 2007b). Mice deficient of GCC signalling exhibit enhanced sensitivity to tumorigenesis induced by $\mathrm{Apc}^{\mathrm{Min} /+}$ and the carcinogen azoxymethane, reflected by increased tumor incidence, multiplicity, and burden (Li et al., 2007b). A principal mechanism by which GCC promotes colorectal tumorigenesis is the perturbation of regulators of $G_{1} / S$ cell cycle transition, including increased expression of oncogenes cyclin $\mathrm{D}_{1}$ and $\mathrm{pRb}$, and decreased activity of tumor suppressor p27 (Li et al., 2007b). Beyond hyperproliferation, GCC-deficient mice also exhibit increased genomic instability in their intestinal mucosa cells. In particular, an increased incidence of DNA breaks, loss of heterozygosity and point mutations in genes central to tumorigenesis, including APC and $\beta$ catenin, are observed along the crypt-villus axis ( $\mathrm{Li}$ et al., 2007b). Although it remains unclear, the molecular mechanism mediating maintenance of the genome by GCC, including damage detection or mutational repair, appears to be distinct from that regulating proliferation ( $\mathrm{Li}$ et al., 2007b). Rather, proliferative restriction and genomic quality control reflect two reinforcing systems by which the GCC pathway opposes intestinal carcinogenesis ( $\mathrm{Li}$ et al., 2007b; Pitari et al., 2007). While accelerated $\mathrm{G}_{1} / \mathrm{S}$ cell cycle transition favours inheritance and amplification of genetic mutations (Aoki et al., 2003; Spruck et al., 1999), instability involving tumor suppressors or oncogenes further deregulates the cancer cell cycle (Spruck et al., 1999).

Another consequence of a dormant GCC pathway in colorectal transformation is the promotion of the cancer cell metabolism (Lin et al., 2010). As discussed above, intestinal crypt stem cells principally rely on glycolysis to produce ATP and support their metabolism. Activation of GCC signalling restricts the glycolytic crypt compartment and favours the acquisition of mitochondria-mediated oxidative phosphorylation by differentiated epithelial cells in villi (Lin et al., 2010). Importantly, neoplastic cells utilize glycolytic ATP as their source of energy, even in the context of optimal environmental oxygen levels (Capuano et 
al., 1997; Kroemer, 2006; Pelicano et al., 2006). Dr. Otto Warburg first described this malignant paradox suggesting that cancer cells undergo metabolic reprogramming, wherein they switch from oxidative phosphorylation to aerobic glycolysis to produce ATP (Warburg, 1956). This malignant transition provides a competitive advantage to cancer cells that have a readily accessible supply of energy and substrates to support proliferation, adapt to the hypoxic tumor microenvironment, and promote invasion. Of relevance, restoration of GCC signalling by exogenous ligand administration increases the number, size and function of mitochondria in human colon cancer cells (Lin et al., 2010). Tumor reversion to mitochondria-dependent oxidative metabolism is associated with concurrent reduction in rate-limiting glycolytic enzymes, and reflects modulation of AKT and its downstream effectors (e.g., mTOR) by GCC signalling reactivation (Lin et al., 2010). Thus, while GCC signalling in human colon cancer cells induces expression of critical transcription factors required for mitochondrial biogenesis (PGC1a, mtTFA, NRF1), inhibition of glycolysis by GCC results in a reduced ability of tumors to uptake glucose and produce lactate (Lin et al., 2010). Importantly, elimination of AKT rescues the tumorigenic intestinal phenotype of mice deficient in GCC signalling (Lin et al., 2010), underscoring the central role of metabolic circuits in mediating inhibition of colorectal carcinogenesis by GCC. Together, these observations suggest that the dormant GCC pathway, produced by hormone deprivation early in transformation (Birkenkamp-Demtroder et al., 2002; Cohen et al., 1998; Notterman et al., 2001; Steinbrecher et al., 2000), can be envisioned as a loss-of-function mutation of a tumor suppressor system, which promotes crypt stem-like proliferation and metabolism and favours genomic instability and the development of the colon cancer cell phenotype.

\subsection{Regulation of the colon tumor microenvironment}

The tumor microenvironment is recognized as a major determinant of cancer formation, growth and dissemination (Fidler, 2001; Kraus \& Arber, 2009; Suzuki et al., 2011). Both cellular and acellular components comprising the tumor stroma contribute to intestinal transformation, reflecting the intimate crosstalk between tumor epithelial cells and the underneath mesenchyme (Kraus \& Arber, 2009; Suzuki et al., 2011; Witz \& LevyNissenbaum, 2006). Thus, interstitial matrix remodelling, secretion of paracrine factors by stromal cells, lymphocyte-mediated immunoresponses, and neo-angiogenesis significantly influence cancer development (Fidler, 2001; Kraus \& Arber, 2009; Suzuki et al., 2011). Among the molecular mediators of cancer-mesenchyme interactions, the matrix metalloproteinases (MMPs) play an essential role (Zucker \& Vacirca, 2004). MMPs are a family of zinc-dependent metalloendopeptidases that cleave interstitial matrix components, growth factors, chemokines and cell surface receptors creating a nurturing niche for cancer growth and invasion (Cox \& O'Byrne, 2001; Curran \& Murray, 2000; McCawley \& Matrisian, 2001). Depending on their substrate specificities, MMPs are divided into collagenases, gelatinases, stromelysins, and matrilysins (Stamenkovic, 2003).

The soluble collagenase MMP-9 has been conclusively linked with colorectal carcinogenesis (Chu et al., 2011; Lubbe et al., 2006; Nascimento et al., 2010; Zucker \& Vacirca 2004; Zuzga et al., 2008). Structurally, MMP-9 (92-kDa protein) consists of a pro-peptide sequence, a catalytic domain containing the zinc binding site and fibronectin type II-like repeats, which promote MMP-9 binding to gelatin and elastin (Fridman et al., 2003; Shipley et al., 1996). Although enzymatic-independent signalling also has been reported (Bjorklund et al., 2004; Librach et al., 1991), the catalytic activity of MMP-9 is the principal mediator of tumor 
matrix remodelling (Fridman et al., 2003; Lubbe et al., 2006). In this way, MMP-9 degrades basement membrane collagen type IV, allowing intestinal tumor epithelial cells to invade the adjacent stromal compartment (Fridman et al., 2003). Moreover, MMP-9 promotes tumor angiogenesis by specifically processing and releasing TGF- $\beta$ and VEGF from cancer cell surfaces and the interstitial matrix, respectively (Bergers et al., 2000; Qian et al., 1997; Yu \& Stamenkovic, 2000). Given its crucial role in those pathological processes, MMP-9dependent proteolytic activity is considered a driving force conferring the migratory and invasive phenotype to cancer cells and favouring tumor progression (Bergers et al., 2000; Fridman et al., 2003; Lubbe et al., 2006; Yu \& Stamenkovic, 2000). Consequently, MMP-9 activity needs to be tightly controlled in biological tissues. Indeed, normally MMP-9 is a silent protease, secreted by cancer cells as a pro-zymogen that is activated only upon cleavage of its 10-kDa N-terminal pro-peptide by various proteases (e.g., MMP-2, MMP-3, MMP-13, plasmin, thrombin) (Ahmed et al., 2003; Fridman et al., 2003; Ramos-DeSimone et al., 1999). Endogenous inhibitors of MMP-9 also exists (e.g., the tissue inhibitor of matrix metalloproteinase 1) which bind to both the pro- and the active-form of MMP-9 and neutralize its proteolytic activity (Goldberg et al., 1992; Stamenkovic, 2003).

Beyond inhibition of catalytic activity, regulation of zymogen expression and secretion represents additional effective modalities to contain tumorigenic MMP-9 functions (St-Pierre et al., 2003; Zhang et al., 2006). Cyclic GMP inhibits the synthesis and secretion of MMP-9 in various cell systems (Akool el et al., 2003; Gurjar et al., 1999). Accordingly, restoration of ligand-dependent GCC signalling though cGMP induces a compartmental redistribution of colon cancer cell MMP-9, in which intracellular retention results in reciprocal extracellular depletion of that collagenase (Lubbe et al., 2009). As a consequence, MMP-9 proteolytic activities at the pericellular tumor space are suppressed, with abrogation of MMP-9dependent interstitial matrix remodelling and cell spreading (Lubbe et al., 2009). Conversely, mutational dormancy of the GCC pathway early in transformation (Birkenkamp-Demtroder et al., 2002; Cohen et al. 1998; Notterman et al., 2001; Steinbrecher et al., 2000) may permit the emergence of a pro-tumorigenic stromal environment characterized by increased MMP-9 secretion, break-down of epithelial basement membranes by MMP-9 catalytic activity and disruption of homeostatic epithelial-mesenchymal interactions. It has been proposed that GCC effect on spatiotemporal MMP-9 dynamics in colon cancer cells has a profound impact on the overall tumor phenotype, because by disrupting its surface localization, membrane anchoring and focal catalytic activity it suppresses oncogenic MMP-9 functions (Lubbe et al., 2009).

\section{GCC and colorectal cancer metastasis}

Cancer metastasis consists in the dissemination of tumor cells to distant locations (Fidler, 2003). Clinically, metastasis coincides with the most terminal disease stages, incurable conditions associated with poor prognosis and survival (Mehlen \& Puisieux, 2006; Siegel et al., 2011). Pathogenetically, it comprises a sequence of distinct, individual processes including cancer cell invasion of the primary site, intravasation and distribution through blood or lymphatic vessels, and colonization of target organs (Fidler, 2003; Folkman, 1986; Nicolson, 1988). Following organ seeding, tumor cells have to migrate into and invade tissue parenchyma (Wanget al., 2004; Steeg, 2006), resist to local immune defences and establish a nurturing micro-environment to develop and growth (Fidler, 2003; Folkman, 1986). In colon cancer, preferred organs of metastatic colonization include the liver, lung and peritoneum. 
Once colorectal cancer has spread to these organs, the risk of mortality increases dramatically, and $\sim 90 \%$ of patients diagnosed with distant metastasis die within 5 years from diagnosis (Siegel et al., 2011). Indeed, the management of patients with colorectal cancer metastasis is characterized by the highest incidence of therapeutic failure, in which surgery is not practicable (Pihlet al., 1981; Shapiro, 1992) and adjuvant chemotherapy is ineffective (increasing median survival only few months) (Meyerhardt \& Mayer, 2005).

The functional phenotype of metastatic cells is unique and very selective. It has been calculated that of intravasated tumor cells, only a minute fraction remains viable after 24 hour, and $>99.99 \%$ are eliminated before reaching their target organ (Fidler, 1970). This metastatic inefficiency reflects the scarcity of cancer cell clones exhibiting the full molecular machinery to execute all the individual steps comprising the metastatic process (Fidler, 1970; Weiss, 1990). In that context, since its inception primary colorectal cancer consists of biologically heterogeneous cell subpopulations, among which are present those possessing the ability to migrate and spread to distant parenchyma (Fidler, 2003; Heppner, 1984). Intriguingly as demonstrated by extensive immune detection and mRNA analyses of clinical specimens, GCC is uniformly expressed in metastatic colon tumors regardless of anatomical location (Carrithers et al., 1994; Carrithers et al., 1996; Waldman et al., 1998). Moreover, the structural and functional integrity of GCC and its principal downstream effectors appears to be preserved in metastasis, as colorectal cancer cells at extra-intestinal sites exhibit identical binding characteristics to, and signalling activation by, the exogenous ligand ST to those of normal intestinal cells (Carrithers et al., 1994; Schulz et al., 2006; Witek et al., 2005). However away from its primary organ, GCC is a ligand-starved receptor with an intracellular dormant pathway, as normal mucosal cells in intestine are the principal producers of endogenous hormones guanylin and uroguanylin (Forte, 1999). Thus, the loss of GCC ligand expression early in transformation (Birkenkamp-Demtroder et al., 2002; Cohen et al., 1998; Notterman et al., 2001; Steinbrecher et al., 2000) may be part of the exclusive phenotypic mutations conferring a pro-metastatic evolutionary advantage to selected colon cancer clones (Lubbe et al., 2009; Pitari et al., 2007; Zuzga et al., 2011).

\subsection{Control of invasive cell shape}

To successfully execute the metastatic program, transformed cells require a dynamic actin cytoskeleton. Thus, a hallmark of metastasis is the abandon of the static epithelial cell polarity and the acquisition of plastic membrane borders with specialized actin-based organelles promoting locomotion and invasion (Fidler, 2003; Steeg, 2006). Similarly to lymphocytes or neutrophils at inflammatory sites, cancer cells constantly remodel their actin to assume atypical morphological architectures, a process often referred to as epithelialmesenchymal transition (Polyak \& Weinberg, 2009). Changes in cell shapes reflect profound molecular rearrangements at tumor surfaces, including loss of E-cadherin-dependent cellcell contacts and transient assembly of integrin-driven cell-matrix adhesions (Avizienyte et al., 2004, 2005; Polyak \& Weinberg, 2009). These processes permit de novo development of membrane protrusions, such as filopodia and lamellipodia for probing the matrix during spreading and migration, and invadopodia for focal proteolytic matrix degradation in invasion (Linder, 2007; Yamaguchi \& Condeelis, 2007).

In general, common molecular regulators coordinate tumor cytoskeletal remodelling by transducing external signals into actin processes. In colon cancer cells, tyrosine kinase receptors (e.g., EGF receptor, Eph receptors, Met receptors), G protein-coupled receptors 
(e.g., cholecystokinin receptors) and cytokine receptors (e.g., chemokine receptors, TGF- $\beta$ receptor) have been established as important inducers of the metastatic cell morphology (Dienstmann \& Tabernero 2010; Dong et al., 2009; Fulton, 2009; Kitamura et al., 2010; Larsen \& Dashwood, 2010; Ongchin et al., 2009; Yuet al., 2006). They activate the intracellular signalling system controlling cytoskeletal actin (e.g., focal adhesion kinases, rho-GTPases, Arp2/3 complex), which assembles the membrane protrusive structures mediating invasion (Linder, 2007; Yamaguchi \& Condeelis, 2007). Normally restricted at intestinal epithelial brush borders (Lucas et al., 2000), GCC is ideally positioned to affect those molecular networks and exert spatio-temporal control of actin remodelling. Indeed, ligand-dependent GCC signalling through cGMP appears to act as a suppressor of metastatic cell morphology in intestine (Lubbe et al., 2009; Zuzga et al., 2011). Thus, colon cancer cells assume a rounded shape upon GCC signalling activation, with elimination of F-actin rich filopodia and lamellipodia (Lubbe et al., 2009). The number and length of cancer cell invadopodia also significantly decreases after activation of the GCC pathway (Zuzga et al., 2011). Importantly, failure to form protrusive structures forces tumor cells to aggregate into compact colonies devoid of spreading and invading abilities (Lubbe et al., 2009; Zuzga et al., 2011). Together, these observations suggest that the GCC pathway is one of the intrinsic homeostatic systems that maintain the stable epithelial cell polarity, shape and tight junctions, which form the essential mucosal barrier between the intestine and the external environment (Han et al., 2011). This notion is further supported by the inhibitory role that GCC signalling exerts on known inducers of epithelial-mesenchymal transition (Polyak \& Weinberg, 2009), including the reactive stromal environment (with enhanced TGF- $\beta$ and MMP-9 activities) (Gibbons et al., 2009) and the stem cell-promoting PI3K/AKT system (Lin et al., 2010). Hence, dysregulation of GCC signalling in intestinal tumorigenesis may enable the epithelialmesenchymal transition required for cancer cell dissemination (Lubbe et al., 2009).

A key intracellular effector of the GCC pathway that regulates colon cancer cell shape is the vasodilator-stimulated phosphoprotein (VASP) (Zuzga et al., 2011). Ena/VASP family proteins control F-actin geometry supporting cell motility (Krause et al., 2003). VASP promotes filopodia and lamellipodia formation and extension by organizing molecular complexes comprising G-actin, F-actin and actin regulatory proteins (Krause et al., 2003). It functions by protecting actin barbed ends from binding to capping proteins, thereby permitting filament elongation (Bear et al., 2002; Mejillano et al., 2004). Three critical domains enable VASP to intimately interact with the actin cytoskeleton (Krause et al., 2003), including 1) the N-terminus Ena/VASP homology 1 (EVH1), which binds to focal adhesion proteins vinculin and zyxin, 2) the central prolin-rich region, which contains a consensus binding motif for the G-actin-binding protein profilin, and 3) the C-terminus EVH2, which binds to both G- and F-actin and mediates VASP oligomerization. Importantly, Ser239 within the EVH2 VASP domain is a preferred phosphorylation site for PKG, functioning as a biological marker for cGMP signalling in intestinal (Deguchi et al., 2002) and other cells (Krause et al., 2003; Yaroslavskiy et al., 2005). Cyclic GMP-dependent VASP phosphorylation inhibits membrane protrusion formation in normal cells (Krause et al., 2003; Lindsay et al., 2007). Accordingly, in colorectal cancer cells VASP Ser239 phosphorylation induced by ligand activation of GCC signalling through cGMP and PKG induces rapid disassembly (less than 10 minutes) of invasive and migratory membrane organelles (Zuzga et al., 2011). Herein, GCC promotes VASP removal from tumor membrane protrusions with subsequent collapse of the F-actin infrastructure supporting 
filopodia and invadopodia (Zuzga et al., 2011). However, colorectal cancer cells expressing a mutant VASP construct not-phosphorylatable at Ser239 are resistant to GCC effects on VASP intracellular distribution and membrane protrusions (Zuzga et al., 2011). These findings are the most significant because they uncover the novel paradigm of a single intracellular biochemical reaction, VASP Ser239 phosphorylation, as an invasion suppressive mechanism for colon cancer (Zuzga et al., 2011). Hence, the loss of this mechanism during colorectal tumorigenesis, reflecting silencing of the GCC-cGMP-VASP system following hormonal deprivation (Birkenkamp-Demtroder et al., 2002; Cohen et al., 1998; Notterman et al., 2001; Steinbrecher et al., 2000), may favour the acquisition of the metastatic cell morphology, characterized by dissolution of normal cell-matrix and cell-cell contacts, increased actin polymerization dynamics, and enhanced formation of membrane protrusions (Zuzga et al., 2011).

\subsection{Control of cancer cell dissemination}

Relocation of cancer cells to distant sites requires acquisition of novel motor abilities, enabling them to spread through remodelled matrix surfaces at both primary and secondary tissues. In primary tumors, cancer cell spreading in the direction of blood vessels initiates the migratory journey of the intravasation process (Fidler et al., 1978; Fidler, 2003). In secondary organs, tumor cell adhesion and spreading onto vascular endothelial surfaces starts cancer invasion of target parenchyma (Im et al., 2004; Wang et al., 2004). In this context, polarized cell spreading drives cancer cell migration in the direction of invasion by permitting the establishment of specialized cell-matrix contacts at membrane protrusions, which mediates actin cytoskeleton-driven anchorage and traction of the cell body (Small et al., 1996). Thus, regulators of the cytoskeleton, adhesion receptors and extracellular proteases, which universally control spreading and migration in cells, are key players underlying cancer dissemination (Yamaguchi \& Condeelis, 2007). Since its signalling through cGMP and VASP controls actin cytoskeletal dynamics and membrane protrusions in colon cancer cells (Zuzga et al., 2011), the GCC pathway may exert substantial impacts on those processes underlying formation of distant metastasis. Consistent with this hypothesis, elimination of GCC signalling in mice accelerates cell migration along the intestinal cryptvillus axis ( $\mathrm{Li}$ et al., 2007a). Of relevance, basal GCC activity appears insufficient to restraining epithelial cell motility, as demonstrated by the increased migration of intestinal mucosa cells in mice with targeted ligand (guanylin) deletion (Steinbrecher et al., 2002). These observations suggest a model in which loss of hormone expression at the beginning of colorectal tumorigenesis (Birkenkamp-Demtroder et al., 2002; Cohen et al., 1998; Notterman et al., 2001; Steinbrecher et al., 2000) results in the acquisition of increased migratory abilities by transformed cells, driven by the accelerated formation of locomotory organelles mediating cell spreading and invasion (Zuzga et al., 2011).

A significant regulator of colorectal cancer cell migration and dissemination is the MMP-9 secreted by tumor epithelial cells (Lubbe et al., 2006). Beyond matrix degradation, this MMP-9 promotes the spreading and migration of colon cancer cells along two dimensional surfaces (Lubbe et al., 2006). Moreover, the catalytic activity of cancer cell MMP-9 is required for optimal colon tumor cell seeding of target mouse organs (Lubbe et al., 2006), an effect probably reflecting remodelling of the tumor pericellular microenvironment by MMP9 (Fridman et al., 2003). Accordingly, inhibitors of MMP-9 suppress the formation of colorectal liver metastasis in an animal model (Aparicio et al., 1999). The significance of 
MMP-9 for colon cancer metastasis is further underscored by its universal role in regulating migration and invasion across different cell types (Buisson et al., 1996; Leppert et al., 1995; Sanceau et al., 2003; Schultz et al., 1988; Yu \& Stamenkovic, 1999). Importantly, liganddependent GCC signalling through cGMP suppresses the function of the MMP-9 produced by colorectal cancer cells (Lubbe et al., 2009). Activation of the GCC pathway suppresses tumor cell spreading, migration and dissemination by specifically inhibiting the secretion of cancer cell MMP-9 in the extracellular space (Lubbe et al., 2009). Further, colon tumor cells treated with GCC ligands fail to form metastatic colonies on mouse diaphragms following intraperitoneal injections (Lubbe et al., 2009). This effect also depends on the ability of GCC to inhibit cancer cell MMP-9, as demonstrated by the resistance of cells overexpressing MMP-9 to GCC-mediated inhibition of peritoneal metastasis (Lubbe et al., 2009). Conceivably, a silent GCC pathway in colorectal carcinogenesis (Birkenkamp-Demtroder et al., 2002; Cohen et al., 1998; Notterman et al., 2001; Steinbrecher et al., 2000) facilitates colon tumor invasion and metastatic dissemination by removing a key inhibitory mechanism restraining the oncogenic activity of cancer cell MMP-9.

\section{The GCC pathway as a source of novel clinical targets}

As discussed above, the loss of ligand-dependent GCC signalling produces a dormant GCC/cGMP pathway, which has significant impacts on the initiation, progression and metastasis of colorectal cancer. Conversely, deregulation of that pathway and its individual molecular components uncovers novel targets with unexploited clinical potential for improved diagnosis and therapy of patients. Thus, detection of hormone downregulation in colon biopsies could indicate presence of intestinal carcinogenesis and demand appropriate follow-up (Cohen et al., 1998; Notterman et al., 2001). The selective expression of GCC in colorectal tumor cells at metastatic sites (Carrithers et al., 1994, 1996; Waldman et al., 1998), suggests its utility as a diagnostic marker and specific target for delivering imaging and therapeutic agents in vivo (Gali et al., 2001; Wolfe et al., 2002). Indeed, clinical trials are confirming the value of GCC as a diagnostic marker for molecular staging of patients and prognostic indicator of colorectal cancer recurrence (Mejia et al., 2010; Waldman et al., 2009). Moreover, the structural preservation of GCC and its intracellular effectors offers the GCC hormone replacement therapy as a novel clinical paradigm for the prevention and treatment of colorectal cancer (Pitari et al., 2007). In this context, oral administration of uroguanylin prevents polyp formation in an animal model of intestinal tumorigenesis (Shailubhai et al., 2000). Further, the resistance to colon cancer initiation and progression exhibited by populations living in the developing world (Pitari et al., 2003; Shailubhai et al., 2000), where enterotoxigenic infections are highest, suggests that replacement therapy with the exogenous GCC ligand ST, the enterotoxin produced by E. coli, might be an effective treatment for colorectal cancer patients (Pitari et al., 2007). This latter consideration is supported by observations that ST is the most potent GCC agonist available (Lucas et al., 2000), and the only ligand successfully investigated to fully restore the tumor suppressor activities of the GCC pathway in colorectal cancer cells (Lubbe et al., 2009; Pitari et al., 2001, 2003, 2005, 2007; Zuzga et al.,2011).

Distal components of the GCC pathway also could be exploited in original clinical applications against colon cancer. As expected for its significance in intestinal mucosa homeostasis, the intracellular GCC signalome comprises a complex molecular network 
(Pitari et al., 2007), probably still incomplete and in which each of the molecular elements may deserve critical translational evaluations. For some of these, preclinical testing is currently ongoing that is revealing emerging features as promising colorectal cancer biotargets (Table 1). One model is the CaR, whose surface expression in colon cancer cells is conditionally regulated by activation of GCC signalling (Pitari et al., 2008). The dormant GCC pathway probably contributes to the reduced CaR expression observed in colorectal tumors (Chakrabarty et al., 2003; Kallay et al., 2003), a mutational event with clinical potential as a diagnostic marker of disease progression (Pitari et al., 2008). Moreover, CaR activation by extracellular $\mathrm{Ca}^{2+}$ inhibits cell proliferation (Chakrabarty et al., 2003), and dietary $\mathrm{Ca}^{2+}$ supplementation has been proposed as a chemopreventive strategy for colon cancer (Cho et al., 2004). Since restoration of the GCC pathway with exogenous ST administration potentiates antitumorigenic $\mathrm{CaR}$ signalling in human colon carcinoma cells (Pitari et al., 2008), combinatorial therapies including dietary $\mathrm{Ca}^{2+}$ and GCC ligand replacement may represent promising clinical regimens for the prevention and treatment of colorectal cancer.

\begin{tabular}{|c|c|c|c|c|}
\hline Protein & $\begin{array}{l}\text { Alteration in Colorectal } \\
\text { Tumorigenesis }\end{array}$ & $\begin{array}{l}\text { Diagnostic } \\
\text { Target }\end{array}$ & $\begin{array}{l}\text { Therapeutic } \\
\text { Target }\end{array}$ & Ref. \\
\hline $\mathrm{CaR}$ & Reduced expression & $\begin{array}{l}\text { Tumor } \\
\text { formation }\end{array}$ & $\begin{array}{l}\text { Inhibition of } \\
\text { tumor } \\
\text { growth }\end{array}$ & $\begin{array}{l}\text { (Chakrabarty et al., } \\
\text { 2003; } \\
\text { Kallay et al., 2003; } \\
\text { Pitari et al., 2008) }\end{array}$ \\
\hline MMP-9 & $\begin{array}{l}\text { Increased cancer cell } \\
\text { secretion }\end{array}$ & $\begin{array}{l}\text { Distant } \\
\text { metastasis }\end{array}$ & $\begin{array}{l}\text { Metastasis } \\
\text { prevention }\end{array}$ & $\begin{array}{l}\text { (Lubbe et al., 2009; } \\
\text { Zuzga et al., 2008) }\end{array}$ \\
\hline VASP & $\begin{array}{l}\text { Loss of Ser } \\
\text { phosphorylation }\end{array}$ & $\begin{array}{l}\text { Invasion, } \\
\text { metastasis }\end{array}$ & $\begin{array}{l}\text { Local } \\
\text { invasion } \\
\text { prevention }\end{array}$ & (Zuzga et al., 2011) \\
\hline
\end{tabular}

Table 1. Examples of emergent colon cancer molecular targets from the GCC pathway.

Another intriguing effector of the GCC pathway is MMP-9, whose cancer cell compartmentalization depends on intracellular cGMP signalling (Lubbe et al., 2009). A silent GCC network may favour increased release and proteolytic activity of MMP-9 at the tumor pericellular space (Lubbe et al., 2009), thereby promoting matrix remodelling and invasion (Curran \& Murray, 1999). Importantly, colon cancer cell MMP-9 behaves as a selective prognostic and predictive biomarker for disease stage stratification and therapeutic regimen selection in patients (Bendardaf et al., 2010; Zuzga et al., 2008). Reactivation of the GCC pathway with ST, in turn, is one successful strategy to specifically inhibit MMP-9 in tumor epithelial cells, without collateral damage in normal tissue, that has been suggested for the chemoprevention of colorectal cancer metastasis (Lubbe et al., 2009). Further, recent studies are indicating VASP as yet another GCC target with attractive translational applications for patients with colon cancer (Zuzga et al., 2011). VASP is a crucial actin-binding protein controlling membrane protrusion geometry, cell adhesion and migration (Bear et al., 2002; Krause et al., 2003; Mejillano et al., 2004). Dormancy of the GCC pathway in tumorigenesis depletes colon cancer cells of the cGMP-dependent VASP Ser phosho-species, molecular regulators of VASP activity at dynamic membrane regions (Krause et al., 2003). Thus, loss of VASP Ser phosphorylation may represent a novel prognostic biomarker of colon cancer 
progression (Zuzga et al., 2011). Conversely, reconstitution of VASP Ser phosphorylation could be exploited as an original paradigm for the chemoprevention of cancer migration and invasion, because the potent GCC ligand ST suppresses the malignant cell morphology and its pathological functions in colon cancer (Zuzga et al., 2011).

\section{Conclusion}

A novel paradigm is emerging in which colorectal cancer, one of the top cancer killers in the world, is pathogenetically conditioned by a dormant GCC pathway, developed early in tumorigenesis following specific ligand downregulation. Indeed, GCC and its paracrine hormones restrict the proliferative crypt phenotype and promote the normal epithelial cell morphology by orchestrating an articulated intracellular network comprising interconnected, but functionally distinct molecular effectors. Silencing of the pathway for loss of agonist-induced GCC/cGMP signalling alters the activity of those molecules with profound consequences for the initiation and progression of colorectal transformation (Fig. 1). Virtually all the key processes underlying carcinogenesis and metastasis are enhanced by dysregulation of the GCC pathway components, including proliferation, survival, genetic instability, migration, matrix remodelling and invasion. At the same time, the dormant pathway creates unexplored opportunities for novel diagnostic applications. This is because the biochemical deregulation that ensues from the silent cGMP-dependent machinery can be traced by analysis of the single pathway components at the molecular level. As a result, novel molecular fingerprints of colorectal carcinogenesis are emerging from the GCC pathway that can be exploited as clinical prognostic or predictive indicators of disease.

Restoration of the lost function by the GCC pathway in colorectal tumors also is proving its great translational value. Preclinical studies indicate that, though dormant, the pathway is largely intact and can be reconstituted simply by ligand replacement. Thus, administration of bacterial enterotoxin STs, potent GCC agonists, suppresses proliferation, migration, matrix degradation, invasion and metastasis by colorectal cancer cells. Altogether, these findings support the notion that oral replacement therapy with GCC ligands could represent a novel strategy for both the chemoprevention and cure of colorectal cancer. Additional therapies targeting the individual pathway components, either alone or in combination, also are being developed with the goal to improve clinical efficacy and selectivity. However, information from clinical testing is still missing and important questions remain to be addressed before this knowledge could be applied to the patient bed. In particular, general gastrointestinal toxicity worries need to be dissipated as GCC ligands such as ST are known for their potent diarrheagenic effects. Also, the temporal profile of GCC-targeted therapy will require complete characterization, including estimation of duration of treatments and effects. Finally, pharmacokinetics evaluation will need to be performed to accurately define dosing and timing regimens. In summary, the intestinal GCC pathway is an exciting potential source of novel diagnostic and therapeutic targets that could significantly affect the clinical management and disease outcome of patients with colorectal cancer.

\section{Acknowledgment}

This work was supported by grants to GMP from the National Institute of Health (R03CA133950), the Elsa U. Pardee Foundation and the American Institute for Cancer Research. The National Institute of Health specifically disclaims responsibility for any analyses, interpretations or conclusions. 


\section{References}

Ahmed, N., Oliva, K., Wang, Y., Quinn M., \& Rice, G. (2003). Downregulation of urokinase plasminogen activator receptor expression inhibits Erk signalling with concomitant suppression of invasiveness due to loss of uPAR-beta1 integrin complex in colon cancer cells. Br J Cancer, Vol.89, No.2, (July 2003), pp. 374-384, PMID 12865932

Akool el, S., Kleinert, H., Hamada, F.M., Abdelwahab, M.H., Forstermann, U., Pfeilschifter, J., \& Eberhardt, W. (2003). Nitric oxide increases the decay of matrix metalloproteinase $9 \mathrm{mRNA}$ by inhibiting the expression of mRNA-stabilizing factor HuR. Mol Cell Biol, Vol.23, No.14, (July 2003), pp. 4901-4916, PMID 12832476

Ames, J.B., Dizhoor, A.M., Ikura, M., Palczewski, K., \& Stryer, L. (1999). Three-dimensional structure of guanylyl cyclase activating protein-2, a calcium-sensitive modulator of photoreceptor guanylyl cyclases. J Biol Chem, Vol.274, No.27, (July 1999), pp. 1932919337, PMID 10383444

Aoki, K., Tamai, Y., Horiike, S., Oshima, M., \& Taketo, M. M. (2003). Colonic polyposis caused by mTOR-mediated chromosomal instability in Apc+/Delta716 Cdx2+/compound mutant mice. Nat Genet, Vol.35, No.4, (Dec 2003), pp. 323-330, PMID 14625550

Aparicio, T., Kermorgant, S., Dessirier, V., Lewin, M \& Lehy T. (1999). Matrix metalloproteinase inhibition prevents colon cancer peritoneal carcinomatosis development and prolongs survival in rats. Carcinogenesis, Vol.20, No.8, (Aug 1999), pp. 1445-1451, PMID 10426790

Avizienyte, E., Fincham, V.J., Brunton, V.G., \& Frame, M.C. (2004). Src SH3/2 domainmediated peripheral accumulation of Src and phospho-myosin is linked to deregulation of E-cadherin and the epithelial-mesenchymal transition. Mol Biol Cell, Vol.15, No.6, (June 2004), pp. 2794-2803, PMID 15075377

Avizienyte, E., Brunton, V.G., Fincham, V.J., \& Frame M.C. (2005). The SRC-induced mesenchymal state in late-stage colon cancer cells. Cells Tissues Organs, Vol.179, No.1-2, (June 2005), pp. 73-80, PMID 15942195

Bear, J.E., Svitkina, T.M., Krause, M., Schafer, D.A., Loureiro, J.J., Strasser, G.A., Maly, I.V., Chaga, O.Y., Cooper, J.A., Borisy, G.G., \& Gertler, F.B. (2002). Antagonism between Ena/VASP proteins and actin filament capping regulates fibroblast motility. Cell, Vol.109, No.4, (May 2002) pp. 509-521, PMID 12086607

Bendardaf, R., Buhmeida, A., Hilska, M., Laato, M., Syrjanen, S., Syrjanen, K., Collan Y., \& Pyrhonen S. (2010). MMP-9 (gelatinase B) expression is associated with disease-free survival and disease-specific survival in colorectal cancer patients. Cancer Invest, Vol.28, No.1, (Jan 2010), pp. 38-43, PMID 20001295

Bergers, G., Brekken, R., McMahon, G., Vu, T.H., Itoh, T., Tamaki, K., Tanzawa, K., Thorpe, P., Itohara, S., Werb, Z., \& Hanahan, D. (2000). Matrix metalloproteinase-9 triggers the angiogenic switch during carcinogenesis. Nat Cell Biol, Vol.2, No.10, (Oct 2000), pp. 737-744, PMID 11025665

Berridge, M.J., Lipp, P., \& Bootman, M.D. (2000). The versatility and universality of calcium signalling. Nat Rev Mol Cell Biol, Vol.1, (Oct 2000), pp. 11-21, PMID 11413485

Biel, M., Zong, X., Ludwig, A., Sautter, A., \& Hofmann, F. (1999). Structure and function of cyclic nucleotide-gated channels. Rev Physiol Biochem Pharmacol, Vol.135, pp. 151171, PMID 9932483

Birkenkamp-Demtroder, K., Christensen, L.L., Olesen, S.H., Frederiksen, C.M., Laiho, P., Aaltonen, LA., Laurberg, S., Sorensen, F.B., Hagemann, R., \& TF, O.R. (2002). Gene 
expression in colorectal cancer. Cancer Res, Vol.62, No.15, (Aug 2002), pp. $4352-$ 4363, PMID 12154040

Bishop, JM.,\&Weinberg, RA. (Eds.). (1996). Molecular Oncology, SA Inc., New York

Bjorklund, M., Heikkila, P., \& Koivunen, E. (2004). Peptide inhibition of catalytic and noncatalytic activities of matrix metalloproteinase-9 blocks tumor cell migration and invasion. J Biol Chem, Vol.279, No.28, (July 2004), pp. 29589-29597, PMID 15123665

Browning, D.D., Kwon, I.K., \& Wang, R. (2010). cGMP-dependent protein kinases as potential targets for colon cancer prevention and treatment. Future Med Chem, Vol.2, No.1, (Jan 2010), pp. 65-80, PMID21426046

Bry, L., Falk, P., Huttner, K., Ouellette, A., Midtvedt, T., \& Gordon, J.I. (1994). Paneth cell differentiation in the developing intestine of normal and transgenic mice. Proc Natl Acad Sci U S A, Vol.91, No.22, (Oct 1994), pp. 10335-10339, PMID 7937951

Buisson, A.C., Zahm, J.M., Polette, M., Pierrot, D., Bellon, G., Puchelle, E., Birembaut, P., \& Tournier, J.M. (1996). Gelatinase B is involved in the in vitro wound repair of human respiratory epithelium. J Cell Physiol, Vol.166, No.2, (Feb 1996), pp. 413-426, PMID 8592002

Capuano, F., Guerrieri, F., \& Papa, S. (1997). Oxidative phosphorylation enzymes in normal and neoplastic cell growth. J Bioenerg Biomembr, Vol.29, No.4, (Aug 1997), pp. 379384, PMID 9387098

Carrithers, S.L., Parkinson, S.J., Goldstein S., Park, P., Robertson, D.C., \& Waldman, S.A. (1994). Escherichia coli heat-stable toxin receptors in human colonic tumors. Gastroenterology, Vol.107, No.6, (Dec 1994) pp. 1653-1661, PMID 7958675

Carrithers, S.L., Barber, M.T., Biswas, S., Parkinson, S.J., Park, P.K., Goldstein, S.D., \& Waldman, S.A. (1996). Guanylyl cyclase C is a selective marker for metastatic colorectal tumors in human extraintestinal tissues. Proc Natl Acad Sci U S A, Vol.93, No.25, (Dec 1996), pp. 14827-14832, PMID 8962140

Chakrabarty, S., Radjendirane, V., Appelman, H., \& Varani, J. (2003). Extracellular calcium and calcium sensing receptor function in human colon carcinomas: promotion of Ecadherin expression and suppression of beta-catenin/TCF activation. Cancer Res, Vol.63, No.1, (Jan 2003), pp. 67-71, PMID 12517779

Chakrabarty, S., Wang, H., Canaff, L., Hendy, G.N., Appelman, H. \& Varani, J. (2005). Calcium sensing receptor in human colon carcinoma: interaction with $\mathrm{Ca}(2+)$ and 1,25-dihydroxyvitamin D(3). Cancer Res, Vol. 65, No.2, (Jan 2005), pp. 493-498, PMID 15695393

Chao, A.C., de Sauvage, F.J., Dong, Y.J., Wagner, J.A., Goeddel, D.V., and Gardner, P. (1994). Activation of intestinal CFTR Cl- channel by heat-stable enterotoxin and guanylin via cAMP-dependent protein kinase. EMBO J, Vol.13, No.5, (March 1994), pp. 10651072, PMID 7510634

Cho, E., Smith-Warner, S.A., Spiegelman, D., Beeson, W.L., van den Brandt, P.A., Colditz, G.A., Folsom, A.R., Fraser, G.E., Freudenheim, J.L., Giovannucci, E., Goldbohm, R.A., Graham, S., Miller, A.B., Pietinen, P., Potter, J.D., Rohan, T.E., Terry, P., Toniolo, P., Virtanen, M.J., Willett, W.C., Wolk, A., Wu, K., Yaun, S.S., ZeleniuchJacquotte A., \& Hunter, D.J. (2004). Dairy foods, calcium, and colorectal cancer: a pooled analysis of 10 cohort studies. J Natl Cancer Inst, Vol.96, No.13, (July 2004) pp. 1015-1022, PMID 15240785 
Chu, D., Zhao, Z., Zhou, Y., Li, Y., Li, J., Zheng, J., Zhao, Q., \& Wang, W. (2011). Matrix Metalloproteinase-9 Is Associated with Relapse and Prognosis of Patients with Colorectal Cancer. Ann Surg Oncol, (Epub ahead of print), PMID 21455597

Cohen, M.B., Witte, D.P., Hawkins J.A., \& Currie, M.G. (1995). Immunohistochemical localization of guanylin in the rat small intestine and colon. Biochem Biophys Res Commun, Vol.209, No.3, (April 1995), pp. 803-808, PMID 7733972

Cohen, M.B., Hawkins, J.A., \& Witte, D.P. (1998). Guanylin mRNA expression in human intestine and colorectal adenocarcinoma. Lab Invest, Vol.78, No.1, (Jan 1998), pp. 101-108, PMID 9461126

Corbin, J.D., \& Francis, S.H. (1999). Cyclic GMP phosphodiesterase-5: target of sildenafil. J Biol Chem, Vol.274, No.20, (May 1999), pp. 13729-13732, PMID 10318772

Cox, G., \& O'Byrne, K.J. (2001). Matrix metalloproteinases and cancer. Anticancer Res, Vol.21, No.6B, (Nov-Dec 2001), pp. (4207-4219), PMID 11908674

Curran, S., \& Murray, G.I. (1999). Matrix metalloproteinases in tumour invasion and metastasis. J Pathol, Vol.189, No.3, (Nov 1999) pp. 300-308, PMID 10547590

Curran, S., \& Murray, G.I. (2000). Matrix metalloproteinases: molecular aspects of their roles in tumour invasion and metastasis. Eur J Cancer, Vol.36, No.13 Spec no, (Aug 2000), pp. 1621-1630, PMID 10959048

Deguchi, A.J., Soh, W., Li, H., Pamukcu, R., Thompson, W.J., \& Weinstein, I.B. (2002). Vasodilator-stimulated phosphoprotein (VASP) phosphorylation provides a biomarker for the action of exisulind and related agents that activate protein kinase G. Mol Cancer Ther, Vol.1, No.10, (Aug 2001), pp. 803-809, PMID 12492114

Di Guglielmo, M.D., Park, J., Schulz, S., \& Waldman, S.A. (2001). Nucleotide requirements for CDX2 binding to the cis promoter element mediating intestine-specific expression of guanylyl cyclase C. FEBS Lett, Vol.507, No.2, (Oct 2001), pp. 128-132, PMID 11684084

Dienstmann, R. ,\& Tabernero, J. (2010). Necitumumab, a fully human IgG1 mAb directed against the EGFR for the potential treatment of cancer. Curr Opin Investig Drugs, Vol.11, No.12, (Dec 2010), pp. 1434-1441, PMID 21154125

Dong, Y., Wang, J., Sheng, Z., Li, G., Ma, H., Wang, X., Zhang, R., Lu, G., Hu, Q., Sugimura, H., \& Zhou, X. (2009). Downregulation of EphA1 in colorectal carcinomas correlates with invasion and metastasis. Mod Pathol, Vol.22, No.1, (Jan 2009) pp. 151-160, PMID 19011600

Fidler, I.J. (1970). Metastasis: guantitative analysis of distribution and fate of tumor embolilabeled with 125 I-5-iodo-2'-deoxyuridine. J Natl Cancer Inst, Vol.45, No.4, (Oct1 970), pp. 773-782, PMID 5513503

Fidler, I.J., Gersten, D.M., \& Hart, I.R. (1978). The biology of cancer invasion and metastasis. Adv Cancer Res, Vol.28, pp. (149-250), PMID 360795.

Fidler, I.J. (2001). Seed and soil revisited: contribution of the organ microenvironment to cancer metastasis. Surg Oncol Clin N Am, Vol.10, No.2, (April 2001), pp. 257-269, PMID 11382586

Fidler, I.J. (2003). The pathogenesis of cancer metastasis: the 'seed and soil' hypothesis revisited. Nat Rev Cancer, Vol.3, No.6, (Jun 2003), pp. 453-458, PMID 12778135

Fodde, R., Kuipers, J., Rosenberg, C., Smits, R., Kielman, M., Gaspar, C., van Es, J.H., Breukel, C., Wiegant, J., Giles, R.H., \& Clevers, H. (2001). Mutations in the APC tumour suppressor gene cause chromosomal instability. Nat Cell Biol, Vol.3, No.4, (April 2001), pp. 433-438, PMID 11283620 
Folkman, J. (1986). How is blood vessel growth regulated in normal and neoplastic tissue? G.H.A. Clowes memorial Award lecture. Cancer Res, Vol.46, No.2, (Feb 1986), pp. 467-473, PMID 2416426

Forte, L.R. (1999). Guanylin regulatory peptides: structures, biological activities mediated by cyclic GMP and pathobiology. Regul Pept, Vol.81, No.1-3, (May 1999), pp. 25-39, PMID 10395405

Francis, S.H., Blount M.A., \& Corbin, J.D. (2011). Mammalian cyclic nucleotide phosphodiesterases: molecular mechanisms and physiological functions. Physiol Rev, Vol.91, No.2, (Apr 2011), pp. 651-690, PMID 21527734

Fridman, R., Toth, M., Chvyrkova, I., Meroueh, S.O., \& Mobashery, S. (2003). Cell surface association of matrix metalloproteinase-9 (gelatinase B). Cancer Metastasis Rev, Vol.22, No.2-3, (Jun-Sep 2003), pp. 153-166, PMID 12784994

Fulton, A.M. (2009). The chemokine receptors CXCR4 and CXCR3 in cancer. Curr Oncol Rep, Vol.11, No.2, (Mar 2009), pp. 125-131, PMID 19216844

Gali, H., Sieckman, G.L., Hoffman, T.J., Owen, N.K., Chin, D.T., Forte, L.R., \& Volkert, W.A. (2001). In vivo evaluation of an 111In-labeled ST-peptide analog for specifictargeting of human colon cancers. Nucl Med Biol, Vol.28, No.8, (Nov 2001), pp. $903-$ 909, PMID 11711309

Gama, L., Baxendale-Cox, L.M., \& Breitwieser, G.E. (1997). Ca2+-sensing receptors in intestinal epithelium. Am J Physiol, Vol.273, No.4Pt1, (Oct 1997), pp. C1168-C1175, PMID 9357760

Gibbons, A.V., Snook, A.E., Li, P., Lin, J.E., DeGodoy, M., Rattan, S.C., Dasgupta, A., Schulz, S., Pitari, G.M., \& Waldman, S.A. (2009). The intestinal tumor susceptibility gene product GUCY2C coordinates epithelial-mesenchymal interactions opposing the tumorigenic stromal niche through TGF- $\beta_{1}$, Proceedings of American Association for Cancer Research Annual Meeting, Denver (CO), Apr 2009

Goldberg, G.I., Strongin, A., Collier, I.E., Genrich, L.T., \& Marmer, B.L. (1992). Interaction of 92-kDa type IV collagenase with the tissue inhibitor of metalloproteinases prevents dimerization, complex formation with interstitial collagenase, and activation of the proenzyme with stromelysin. J Biol Chem, Vol.267, No.7, (March 1992), pp. 45834591, PMID 1311314

Gong, R., Ding, C., Hu, J., Lu, Y., Liu, F., Mann, E., Xu, F., Cohen, MB., \& Luo M. (2011). Role for the Membrane Receptor Guanylyl Cyclase-C in Attention Deficiency and Hyperactive Behavior. Science, (Epub ahead of print), PMID 21835979

Gregorieff, A., \& Clevers, H. (2005). Wnt signaling in the intestinal epithelium: from endoderm to cancer. Genes Dev, Vol. 19, No.8, (April 2005), pp. 877-890, PMID 15833914

Gryfe, R., Swallow, C., Bapat, B., Redston, M., Gallinger, S., \& Couture, J. (1997). Molecular biology of colorectal cancer. Curr Probl Cancer, Vol.21, No.5, (Sept-Oct 1997), pp. 233-300, PMID 9438104

Guarino, A., Guandalini,S., Alessio,M., Gentile,F., Tarallo,L., Capano,G., Migliavacca,M., \& Rubino,A. (1989). Characteristics and mechanism of action of a heat-stable enterotoxin produced by Klebsiella pneumoniae from infants with secretory diarrhea. Pediatr Res, Vol.25, No.5, (May 1989), pp. 514-518, PMID 2470015

Gurjar, M.V., Sharma, R.V., \& Bhalla, R.C. (1999). eNOS gene transfer inhibits smooth muscle cell migration and MMP-2 and MMP-9 activity. Arterioscler Thromb Vasc Biol, Vol.19, No.12, (Dec 1999) pp. 2871-2877, PMID 10591663 
Hamra, F.K., Eber, S.L., Chin, D.T., Currie, M.G., \& Forte, L.R. (1997). Regulation of intestinal uroguanylin/guanylin receptor-mediated responses by mucosal acidity. Proc Natl Acad Sci U S A, Vol.94, No.6, (March 1997), pp. 2705-2710, PMID 9122260

Han, X., Mann, E., Gilbert, S., Guan, Y., Steinbrecher, K.A., Montrose, M.H., \& Cohen, M.B. (2011). Loss of guanylyl cyclase C (GCC) signaling leads to dysfunctional intestinal barrier. PLoS One, Vol.6, No.1, (Jan 2011), pp. e16139, PMID 21305056

Hanahan, D., \& Weinberg, R.A. (2000). The hallmarks of cancer. Cell, Vol.100, No.1, (Jan 2000), pp. 57-70, PMID 10647931

Heppner, G.H. (1984). Tumor heterogeneity. Cancer Res, Vol.44, No.6, (Jun 2000), pp. 22592265, PMID 6372991

Hofer, A.M., \& Brown, E.M. (2003). Extracellular calcium sensing and signalling. Nat Rev Mol Cell Biol, Vol.4, No.7, (July 2003), pp. 530-538, PMID, 12838336

Im, J.H., Fu, W., Wang, H., Bhatia, S.K., Hammer, D.A., Kowalska, M.A., \& Muschel, R.J. (2004). Coagulation facilitates tumor cell spreading in the pulmonary vasculature during early metastatic colony formation. Cancer Res, Vol.64, No.23, (Dec 2004), pp. 8613-8619, PMID 15574768

Jemal, A., Bray, F., Center, M.M., Ferlay, J., Ward, E. \& Forman, D. (2011). Global cancer statistics. CA Cancer J Clin, Vol.61, No.2, (March-Apr 2011), pp. 69-90, PMID 21296855

Kallay, E., Bonner, E., Wrba, F., Thakker, R.V., Peterlik, M., \& Cross, H.S. (2003). Molecular and functional characterization of the extracellular calcium-sensing receptor in human colon cancer cells. Oncol Res, Vol.13, No.12, pp. 551-559, PMID 12899245

Kitamura, T., Fujishita, T., Loetscher, P., Revesz, L., Hashida, H., Kizaka-Kondoh, S., Aoki, M., \& Taketo, M.M. (2010). Inactivation of chemokine (C-C motif) receptor 1 (CCR1) suppresses colon cancer liver metastasis by blocking accumulation of immature myeloid cells in a mouse model. Proc Natl Acad Sci U S A, Vol.107, No.29, (July 2010), pp. 13063-13068, PMID

Koldovsky, O., Dobiasova, M., Hahn, P., Kolinska, J., Kraml, J., \& Pacha, J. (1995). Development of gastrointestinal functions. Physiol Res, Vol.44, No.6, pp. 341-348, PMID 20616008

Korinek, V., Barker, N., Moerer, P., van Donselaar, E., Huls, G., Peters, P.J., \& Clevers, H. (1998). Depletion of epithelial stem-cell compartments in the small intestine of mice lacking Tcf-4. Nat Genet, Vol. 19, No.4, (Aug 1998), pp. 379-383, PMID 8798267

Kraus, S., \& Arber, N. (2009). Inflammation and colorectal cancer. Curr Opin Pharmacol, Vol.9, No.4, (Aug 2009), pp. 405-410, PMID 19589728

Krause, M., Dent, E.W., Bear, J.E., Loureiro, J.J., \& Gertler, F.B. (2003). Ena/VASP proteins: regulators of the actin cytoskeleton and cell migration. Annu Rev Cell Dev Biol, Vol.19, pp. 541-564, PMID 14570581

Kroemer, G. (2006). Mitochondria in cancer. Oncogene, Vol.25, No.34, (Aug 2003) pp. 46304632, PMID 16892077

Larsen, C.A., \& Dashwood, R.H. (2010). (-)-Epigallocatechin-3-gallate inhibits Met signaling, proliferation, and invasiveness in human colon cancer cells. Arch Biochem Biophys, Vol.501, No.1, (Sep 2010), pp. 52-57, PMID 20361925

Leppert, D., Hauser, S.L., Kishiyama, J.L., An, S., Zeng, L., \& Goetzl, E.J. (1995). Stimulation of matrix metalloproteinase-dependent migration of $\mathrm{T}$ cells by eicosanoids. FASEB J, Vol.9, No.14, (Nov 1995), pp. 1473-1481, PMID 7589989

Li, P., Lin, J.E., Chervoneva, I., Schulz, S., Waldman, S.A., \& Pitari, G.M. (2007a). Homeostatic control of the crypt-villus axis by the bacterial enterotoxin receptor 
guanylyl cyclase $\mathrm{C}$ restricts the proliferating compartment in intestine. Am J Pathol, Vol.171, No.6, (Dec 2007), pp. 1847-1858, PMID 17974601

Li, P., Schulz, S., Bombonati, A., Palazzo, J.P., Hyslop, T.M., Xu, Y., Baran, A.A., Siracusa, L.D., Pitari, G.M., \& Waldman, S.A. (2007b). Guanylyl cyclase C suppresses intestinal tumorigenesis by restricting proliferation and maintaining genomic integrity. Gastroenterology, Vol.133, No.2, (Aug 2007), pp. 599-607, PMID

Librach, C.L., Werb, Z., Fitzgerald, M.L., Chiu, K., Corwin, N.M., Esteves, R.A., Grobelny, D., Galardy, R., Damsky, C.H., \& Fisher, S.J. (1991). 92-kD type IV collagenase mediates invasion of human cytotrophoblasts. J Cell Biol, Vol.113, No.2, (April 1991), pp. 437-449, PMID 1849141

Lin, J.E., Li, P., Snook, A.E., Schulz, S., Dasgupta, A., Hyslop, T.M., Gibbons, A.V., Marszlowicz, G., Pitari, G.M., \& Waldman, S.A. (2010). The hormone receptor GUCY2C suppresses intestinal tumor formation by inhibiting AKT signaling. Gastroenterology, Vol.138, No.1, (Jan 2010), pp. 241-254, PMID 19737566

Linder, S. (2007). The matrix corroded: podosomes and invadopodia in extracellular matrix degradation. Trends Cell Biol, Vol.17, No.3, (March 2007), pp. 107-117, PMID 17275303

Lindsay, S.L., Ramsey, S., Aitchison, M., Renne, T., \& Evans, T.J. (2007). Modulation of lamellipodial structure and dynamics by NO-dependent phosphorylation of VASP Ser239. J Cell Sci, Vol.120, No.Pt17, (Sep 2007), pp. 3011-3021, PMID 17684063

Lipkin, M., \& Newmark, H. (1995). Calcium and the prevention of colon cancer. J Cell Biochem Suppl, Vol.22, pp. 65-73, PMID 8538212

Liu, L., Li, H., Underwood, T., Lloyd, M., David, M., Sperl, G., Pamukcu, R., \& Thompson, W.J. (2001). Cyclic GMP-dependent protein kinase activation and induction by exisulind and CP461 in colon tumor cells. J Pharmacol Exp Ther, Vol.299, No.2, (Nov 2001), pp. 583-592, PMID 11602670

Lubbe, W.J., Zhou, Z.Y., Fu, W., Zuzga, D., Schulz, S., Fridman, R., Muschel, R.J., Waldman, S.A., \& Pitari, G.M. (2006). Tumor epithelial cell matrix metalloproteinase 9 is a target for antimetastatic therapy in colorectal cancer. Clin Cancer Res, Vol.12, No.6, (March), pp. 1876-1882, PMID 16551873

Lubbe, W.J., Zuzga, D.S., Zhou, Z., Fu, W., Pelta-Heller, J., Muschel, R.J., Waldman, S.A., \& Pitari, G.M. (2009). Guanylyl cyclase C prevents colon cancer metastasis by regulating tumor epithelial cell matrix metalloproteinase-9. Cancer Res, Vol.69, No.8, (April 2009), pp. 3529-3536, PMID 19336567

Lucas, K.A., Pitari, G.M., Kazerounian, S., Ruiz-Stewart, I., Park, J., Schulz, S., Chepenik, K.P., \& Waldman, S.A. (2000). Guanylyl cyclases and signaling by cyclic GMP. Pharmacol Rev, Vol.52, No.3, (Sep 2000), pp. 375-414, PMID 10977868

McCawley, L.J., \& Matrisian, L.M. (2001). Tumor progression: defining the soil round the tumor seed. Curr Biol, Vol.11, No.1, (Jan 2001), pp. R25-R27, PMID 11166192

Mehlen, P., \& Puisieux, A. (2006). Metastasis: a question of life or death. Nat Rev Cancer, Vol.6, No.6, (Jun 2006), pp. 449-458, PMID 16723991

Mejia, A., Schulz, S., Hyslop, T., Weinberg, D.S., \& Waldman, S.A. (2010). Molecular staging estimates occult tumor burden in colorectal cancer. Adv Clin Chem, Vol.52, pp. 1939, PMID 21275338

Mejillano, M.R., Kojima, S., Applewhite, D.A., Gertler, F.B., Svitkina, T.M., \& Borisy, G.G. (2004). Lamellipodial versus filopodial mode of the actin nanomachinery: pivotal role of the filament barbed end. Cell, Vol.118, No.3, (Aug 2004), pp. 363-373, PMID 15294161 
Meyerhardt, J.A., \& Mayer, R.J. (2005). Systemic therapy for colorectal cancer. N Engl J Med, Vol.352, No.5, (Feb 2005), pp. 476-487, PMID 15689586

Montgomery, R.K., Mulberg, A.E., \& Grand, R.J. (1999). Development of the human gastrointestinal tract: twenty years of progress. Gastroenterology, Vol.116, No.3, (March 1999), pp. 702-731, PMID 10029630

Nascimento, C.F., Gama-De-Souza, L.N., Freitas, V.M., \& Jaeger, R.G. (2010). Role of MMP9 on invadopodia formation in cells from adenoid cystic carcinoma. Study by laser scanning confocal microscopy. Microsc Res Tech, Vol.73, No.2, (Feb), pp. 99-108, PMID 19658178

Nicolson, G.L. (1988). Cancer metastasis: tumor cell and host organ properties important in metastasis to specific secondary sites. Biochim Biophys Acta, Vol.948, No.2, (Nov 1998), pp. 175-224, PMID 3052592

Notterman, D.A., Alon, U., Sierk, A.J., \& Levine, A.J. (2001). Transcriptional gene expression profiles of colorectal adenoma, adenocarcinoma, and normal tissue examined by oligonucleotide arrays. Cancer Res, Vol.61, No.7, (April 2001), pp. 3124-3130, PMID 11306497

Ongchin, M., Sharratt, E., Dominguez, I., Simms, N., Wang, J., Cheney, R., LeVea, C., Brattain, M., \& Rajput, A. (2009). The effects of epidermal growth factor receptor activation and attenuation of the TGF beta pathway in an orthotopic model of colon cancer. J Surg Res, Vol.156, No.2, (Oct 2009), pp. 250-256, PMID 19524264

Park, J., Schulz, S., \& Waldman, S.A. (2000). Intestine-specific activity of the human guanylyl cyclase C promoter is regulated by Cdx2. Gastroenterology, Vol.119, No.1, (July 2000) pp. 89-96, PMID 10889158

Pelicano, H., Martin, D.S., Xu, R.H., \& Huang, P. (2006). Glycolysis inhibition for anticancer treatment. Oncogene, Vol.25, No.34, (Aug 2006), pp. 4633-4646, PMID 16892078

Pfeifer, A., Ruth, P., Dostmann, W., Sausbier, M., Klatt, P., \& Hofmann, F. (1999). Structure and function of cGMP-dependent protein kinases. Rev Physiol Biochem Pharmacol, Vol.135, pp. 105-149, PMID 9932482

Pihl, E., Hughes, E.S., McDermott, F.T., Milne, BJ., \& Price, A.B. (1981). Disease-free survival and recurrence after resection of colorectal carcinoma. J Surg Oncol, Vol.16, No.4, pp. 333-341, PMID 7253653

Pinchuk, I.V., Mifflin, R.C., Saada, J.I., and Powell, D.W. (2010). Intestinal mesenchymal cells. Curr Gastroenterol Rep, Vol.12, No.5, (Oct 2010), pp. 310-318, PMID 20690004

Pinto, D., and Clevers, H. (2005). Wnt, stem cells and cancer in the intestine. Biol Cell, Vol.97, No.3, (Mar 2005), pp. 185-196. PMID 15715524

Pitari, G.M., Di Guglielmo, M.D., Park, J., Schulz, S., and Waldman, S.A. (2001). Guanylyl cyclase $C$ agonists regulate progression through the cell cycle of human colon carcinoma cells. Proc Natl Acad Sci U S A. Vol.98, No.14, (July 2001), pp. 7846-7851, PMID 11438734

Pitari, G.M., Zingman, L.V., Hodgson, D.M., Alekseev, A.E., Kazerounian, S., Bienengraeber, M., Hajnoczky, G., Terzic, A., \& Waldman, S.A. (2003). Bacterial enterotoxins are associated with resistance to colon cancer. Proc Natl Acad Sci U S A, Vol.100, No.5, (March 2003), pp. 2695-2699, PMID 12594332

Pitari, G.M., Baksh, R.I., Harris, D.M., Li, P., Kazerounian, S., and Waldman, S.A. (2005). Interruption of homologous desensitization in cyclic guanosine 3',5'monophosphate signaling restores colon cancer cytostasis by bacterial enterotoxins. Cancer Res, Vol.65, No.23, (Dec 2005), pp. 11129-11135, PMID 16322263 
Pitari, G.M., Li, P., Lin, J.E., Zuzga, D., Gibbons, A.V., Snook, A.E., Schulz, S., \& Waldman, S.A. (2007). The paracrine hormone hypothesis of colorectal cancer. Clin Pharmacol Ther, Vol.82, No.4, (Oct 2007) pp. 441-447, PMID 17687268

Pitari, GM., Lin, J.E., Shah, F.J., Lubbe, W.J., Zuzga, D.S., Li, P., Schulz, S., and Waldman, S.A. (2008). Enterotoxin preconditioning restores calcium-sensing receptormediated cytostasis in colon cancer cells. Carcinogenesis, Vol.29, No.8, (Aug 2008), pp. 1601-1607, PMID 18566015

Polyak, K., \& Weinberg, R.A. (2009). Transitions between epithelial and mesenchymal states: acquisition of malignant and stem cell traits. Nat Rev Cancer, Vol.9, No.4, (April 2009), pp. 265-273, PMID 19262571

Potten, C.S., \& Loeffler, M. (1990). Stem cells: attributes, cycles, spirals, pitfalls and uncertainties. Lessons for and from the crypt. Development, Vol.110, No.4, (Dec 1990), pp. 1001-1020, PMID 2100251

Qian, X., Wang, T.N., Rothman, V.L., Nicosia, R.F., \& Tuszynski, G.P. (1997). Thrombospondin-1 modulates angiogenesis in vitro by up-regulation of matrix metalloproteinase-9 in endothelial cells. Exp Cell Res, Vol.235, No.2, (Sep 1997), pp. 403-412, PMID 9299165

Ramos-DeSimone, N., Hahn-Dantona, E., Sipley, J., Nagase, H., French, D.L., \& Quigley, J.P. (1999). Activation of matrix metalloproteinase-9 (MMP-9) via a converging plasmin/stromelysin-1 cascade enhances tumor cell invasion. J Biol Chem, Vol.274, No.19, (May 1999), pp. 13066-13076, PMID 10224058

Reya, T., and Clevers, H. (2005). Wnt signalling in stem cells and cancer. Nature, Vol.434, No.7035, (April 2005) pp. 843-850, PMID 15829953

Rhee, S.G. (2001). Regulation of phosphoinositide-specific phospholipase C. Annu Rev Biochem, Vol.70, pp. 281-312, PMID 11395409

Rozen, P., Fireman, Z., Fine, N., Wax, Y., \& Ron, E. (1989). Oral calcium suppresses increased rectal epithelial proliferation of persons at risk of colorectal cancer. Gut, Vol.30, No.5, (May 1989), pp. 650-655, PMID 2731758

Sakatani, T., Kaneda, A., Iacobuzio-Donahue, C.A., Carter, M.G., de Boom Witzel, S., Okano, H., Ko, M.S., Ohlsson, R., Longo, D.L., \& Feinberg, A.P. (2005). Loss of imprinting of Igf2 alters intestinal maturation and tumorigenesis in mice. Science, Vol.307, No.5717, (March 2005), pp. 1976-1978, PMID 15731405

Sanceau, J., Truchet, S., \& Bauvois, B. (2003). Matrix metalloproteinase-9 silencing by RNA interference triggers the migratory-adhesive switch in Ewing's sarcoma cells. J Biol Chem, Vol.278, No.38, (Sep 2003), pp. 36537-36546, PMID 12847101

Schulz, S., Singh, S., Bellet, R.A., Singh, G., Tubb, D.J., Chin, H., \& Garbers, D.L. (1989). The primary structure of a plasma membrane guanylate cyclase demonstrates diversity within this new receptor family. Cell, Vol.58, No.6, (Sep 1989), pp. 1155-1162, PMID 2570641

Schulz, S., Hyslop, T., Haaf, J., Bonaccorso, C., Nielsen, K., Witek, M.E., Birbe, R., Palazzo, J., Weinberg, D., \& Waldman, S.A. (2006). A validated quantitative assay to detect occult micrometastases by reverse transcriptase-polymerase chain reaction of guanylyl cyclase $C$ in patients with colorectal cancer. Clin Cancer Res, Vol.12, No.15, (Aug 2006), pp. 4545-4552, PMID 16899600

Schultz, R.M., Silberman, S., Persky, B., Bajkowski, A.S., \& Carmichael, D.F. (1988). Inhibition by human recombinant tissue inhibitor of metalloproteinases of human amnion invasion and lung colonization by murine B16-F10 melanoma cells. Cancer Res, Vol.48, No.19, (Oct 1988), pp. 5539-5545, PMID 3416307 
Shailubhai, K., Yu, H.H., Karunanandaa, K., Wang, J.Y., Eber, S.L., Wang, Y., Joo, N.S., Kim, H.D., Miedema, B.W., Abbas, S.Z., Boddupalli, S.S., Currie, M.G., \& Forte, L.R. (2000). Uroguanylin treatment suppresses polyp formation in the Apc(Min/+) mouse and induces apoptosis in human colon adenocarcinoma cells via cyclic GMP. Cancer Res, Vol.60, No.18, (Sep 2000), pp. 5151-5157, PMID 11016642

Shapiro, S. (1992). Goals of screening. Cancer, Vol.70, No.5, (Sep 1992), pp. 1252-1258, PMID 1511372

Sheinin, Y., Kallay, E., Wrba, F., Kriwanek, S., Peterlik, M., \& Cross, H.S. (2000). Immunocytochemical localization of the extracellular calcium-sensing receptor in normal and malignant human large intestinal mucosa. J Histochem Cytochem, Vol.48, No.5, (May 2000), pp. 595-602, PMID 10769043

Shipley, J.M., Doyle, G.A., Fliszar, C.J., Ye, Q.Z., Johnson, L.L., Shapiro, S.D., Welgus, H.G., \& Senior, R.M. (1996). The structural basis for the elastolytic activity of the 92-kDa and $72-\mathrm{kDa}$ gelatinases. Role of the fibronectin type II-like repeats. J Biol Chem, Vol.271, No.8, (Feb 1996), pp. 4335-4341, PMID 8626782

Siegel, R., Ward, E., Brawley, O., \& Jemal, A. (2011). Cancer statistics, 2011: The impact of eliminating socioeconomic and racial disparities on premature cancer deaths. $C A$ Cancer J Clin, Vol.61, No.4, (July-Aug 2011), pp. 212-236, PMID 21685461

Small, J.V., Anderson, K., \& Rottner, K. (1996). Actin and the coordination of protrusion, attachment and retraction in cell crawling. Biosci Rep, Vol.16, No.5, (Oct 1996), pp. 351-368, PMID 8913526

Spruck, C.H., Won, K.A., \& Reed, S.I. (1999). Deregulated cyclin E induces chromosome instability. Nature, Vol.401, No.6750, (Sep 1999) pp. 297-300, PMID 10499591

St-Pierre, Y., Van Themsche, C., \& Esteve, P.O. (2003). Emerging features in the regulation of MMP-9 gene expression for the development of novel molecular targets and therapeutic strategies. Curr Drug Targets Inflamm Allergy, Vol.2, No.3 (Sep 2003), pp. 206-215, PMID 14561155

Stamenkovic, I. (2003). Extracellular matrix remodelling: the role of matrix metalloproteinases. J Pathol, Vol.200, No.4, (July 2003), pp. 448-464, PMID12845612

Steeg, P.S. (2006). Tumor metastasis: mechanistic insights and clinical challenges. Nat Med, Vol.12, No.8, (Aug 2006), pp. 895-904, PMID 16892035

Steinbrecher, K.A., Tuohy, T.M., Heppner Goss, K., Scott, M.C., Witte, D.P., Groden, J., \& Cohen, MB. (2000). Expression of guanylin is downregulated in mouse and human intestinal adenomas. Biochem Biophys Res Commun, Vol.273, No.1, (Jun 2000), pp. (225-230), PMID 10873591

Steinbrecher, K.A., Wowk, S.A., Rudolph, J.A., Witte, D.P., \& Cohen, M.B. (2002). Targeted inactivation of the mouse guanylin gene results in altered dynamics of colonic epithelial proliferation. Am J Pathol, Vol.161, No.6, (Dec 2002), pp. 2169-2178, PMID 12466132

Steinbrecher, K.A., \& Cohen, M.B. (2011). Transmembrane guanylate cyclase in intestinal pathophysiology. Curr Opin Gastroenterol, Vol.27, No.2, (March 2011), pp. 139-145, PMID 21102322

Suzuki, K., Sun, R., Origuchi, M., Kanehira, M., Takahata, T., Itoh, J., Umezawa, A., Kijima, H., Fukuda, S.,\& Saijo, Y. (2011). Mesenchymal Stromal Cells Promote Tumor Growth through the Enhancement of Neovascularization. Mol Med, Vol.17, No.7-8, pp. 579-587, PMID 21424106

Tang, Y., Katuri, V., Srinivasan, R., Fogt, F., Redman, R., Anand, G., Said, A., Fishbein, T., Zasloff, M., Reddy, E.P., Mishra, B., \& Mishra, L. (2005). Transforming growth 
factor-beta suppresses nonmetastatic colon cancer through Smad4 and adaptor protein ELF at an early stage of tumorigenesis. Cancer Res, Vol.65, No.10, (May 2005), pp. 4228-4237, PMID 15899814

Thompson, W.J., Piazza, G.A., Li, H., Liu, L., Fetter, J., Zhu, B., Sperl, G., Ahnen, D., \& Pamukcu, R. (2000). Exisulind induction of apoptosis involves guanosine 3',5'-cyclic monophosphate phosphodiesterase inhibition, protein kinase $\mathrm{G}$ activation, and attenuated beta-catenin. Cancer Res, Vol.60, No.13, (July 2000), pp. 3338-334, PMID 10910034

van Engeland, M., Derks, S., Smits, K.M., Meijer, G.A., \& Herman, J.G. (2011). Colorectal cancer epigenetics: complex simplicity. J Clin Oncol, Vol.29, No.10, (April 2011), pp. 1382-1391, PMID 21220596

van Es, J.H., Jay, P., Gregorieff, A., van Gijn, M.E., Jonkheer, S., Hatzis, P., Thiele, A., van den Born, M., Begthel, H., Brabletz, T., Taketo, M.M., \& Clevers, H.(2005). Wnt signalling induces maturation of Paneth cells in intestinal crypts. Nat Cell Biol, Vol.7, No.4, (April 2005), pp. 381-386, PMID 15778706

Waldman, S.A., Cagir, B., Rakinic, J., Fry, R.D., Goldstein, S.D., Isenberg, G., Barber, M., Biswas, S., Minimo, C., Palazzo, J., Park, PK., \& Weinberg, D. (1998). Use of guanylyl cyclase $\mathrm{C}$ for detecting micrometastases in lymph nodes of patients with colon cancer. Dis Colon Rectum, Vol.41, No.3, (March 1998), pp. 310-315, PMID 9514425

Waldman, S.A., Hyslop, T., Schulz, S., Barkun, A., Nielsen, K., Haaf, J., Bonaccorso, C., Li, Y., \& Weinberg, DS. (2009). Association of GUCY2C expression in lymph nodes with time to recurrence and disease-free survival in $\mathrm{pN} 0$ colorectal cancer. JAMA, Vol.301, No.7, (Feb 2009), pp. 745-752, PMID 19224751

Wang, H., Fu, W., Im, J.H., Zhou, Z., Santoro, S.A., Iyer, V., DiPersio, C.M., Yu, Q.C., Quaranta,V., Al-Mehdi, A., \& Muschel, R.J. (2004). Tumor cell alpha3beta1 integrin and vascular laminin-5 mediate pulmonary arrest and metastasis. I Cell Biol, Vol.164, No.6, (March 2004), pp. 935-941, PMID 2172296

Warburg, O. (1956). On the origin of cancer cells. Science, Vol.123, No.3191, (Feb 1956), pp. 309-314, PMID 13298683

Weiss, L. (1990). Metastatic inefficiency. Adv Cancer Res, Vol.54, pp. (159-211), PMID 1688681

Whitaker, T.L., Witte, D.P., Scott, M.C., \& Cohen, M.B. (1997). Uroguanylin and guanylin: distinct but overlapping patterns of messenger RNA expression in mouse intestine. Gastroenterology, Vol.113, No.3, (Sep), pp. 1000-1006, PMID 9287995

Whitfield, J.F. (1992). Calcium signals and cancer. Crit Rev Oncog, Vol.3, No.1-2, pp. 55-90, PMID 1550862

Whitfield, J.F., Bird, R.P., Chakravarthy, B.R., Isaacs, R.J., \& Morley, P. (1995). Calcium-cell cycle regulator, differentiator, killer, chemopreventor, and maybe, tumor promoter. J Cell Biochem Suppl, Vol.22, pp. 74-91, PMID 8538213

Witek, M.E., Nielsen, K., Walters, R., Hyslop, T., Palazzo, J., Schulz, S., \& Waldman, S.A. (2005). The putative tumor suppressor Cdx2 is overexpressed by human colorectal adenocarcinomas. Clin Cancer Res, Vol.11, (Dec 2005), pp. 8549-8556, PMID 16361536

Witz, I.P., \& Levy-Nissenbaum, O. (2006). The tumor microenvironment in the post-PAGET era. Cancer Lett, Vol.242, No.1, (Oct 2006), pp. 1-10, PMID 16413116

Wolfe, H.R., Mendizabal, M., Lleong, E., Cuthbertson, A., Desai, V., Pullan, S., Fujii, D.K., Morrison, M., Pither, R. and Waldman, S.A. (2002). In vivo imaging of human colon 
cancer xenografts in immunodeficient mice using a guanylyl cyclase C--specific ligand. J Nucl Med, Vol.43, No.3, (March 2002), pp. 392-399, PMID 11884500

World Health Organization (WHO). (February 2011). Cancer, In: WHO fact sheet $N^{\circ} 297$, 29.07.2011, Available from: http://www.who.int/mediacentre/factsheets/fs297/

Yamaguchi, H., \& Condeelis, J. (2007). Regulation of the actin cytoskeleton in cancer cell migration and invasion. Biochim Biophys Acta, Vol.1773, No.5, (May 2007), pp. 642652, PMID 16926057

Yaroslavskiy, B.B., Zhang, Y., Kalla, S.E., Garcia Palacios,V., Sharrow, A.C., Li, Y., Zaidi, M., $\mathrm{Wu}, \mathrm{C} .$, \& Blair, HC. (2005). NO-dependent osteoclast motility: reliance on cGMPdependent protein kinase I and VASP. J Cell Sci, Vol.118, No.Pt23, (Dec 2005), pp. 5479-5487, PMID 16291726

Yu, H.G., Tong, S.L., Ding, Y.M., Ding, J., Fang, X.M., Zhang, X.F., Liu, Z.J., Zhou, Y.H., Liu, Q.S., Luo, H.S., \& Yu, J.P. (2006). Enhanced expression of cholecystokinin-2 receptor promotes the progression of colon cancer through activation of focal adhesion kinase. Int J Cancer, Vol.119, No.12, (Dec 2006), pp. 2724-2732, PMID 16998832

Yu, Q., \& Stamenkovic, I. (1999). Localization of matrix metalloproteinase 9 to the cell surface provides a mechanism for CD44-mediated tumor invasion. Genes Dev, Vol.13, No.1, (Jan 1999), pp. 35-48, PMID 9887098

Yu, Q., \& Stamenkovic I. (2000). Cell surface-localized matrix metalloproteinase-9 proteolytically activates TGF-beta and promotes tumor invasion and angiogenesis. Genes Dev, Vol.14, No.2, (Jan), pp. 163-176, PMID 10652271

Zhang, Q., Furukawa, K., Chen, H.H., Sakakibara,T., \& Urano T. (2006). Metastatic potential of mouse Lewis lung cancer cells is regulated via ganglioside GM1 by modulating the matrix metalloprotease-9 localization in lipid rafts. J Biol Chem, Vol.281, No.26, (Jun 2006), pp. 18145-18155, PMID 16636068

Zucker, S., \& Vacirca, J. (2004). Role of matrix metalloproteinases (MMPs) in colorectal cancer. Cancer Metastasis Rev, Vol.23, No.1-2, (Jan-Jun 2004), pp. 101-117, PMID 15000152

Zufall, F., Shepherd, GM., \& Barnstable, CJ. (1997). Cyclic nucleotide gated channels as regulators of CNS development and plasticity. Curr Opin Neurobiol, Vol.7, No.3, (Jun 1997), pp. 404-412, PMID 9232810

Zuzga, D.S., Gibbons, A.V., Li, P., Lubbe, W.J., Chervoneva, I. \& Pitari, G.M. (2008). Overexpression of matrix metalloproteinase 9 in tumor epithelial cells correlates with colorectal cancer metastasis. Clin Transl Sci, Vol.1, No.2, (Sep 2008), pp. 136141, PMID 20443834

Zuzga, D.S., Pelta-Heller, J., Li, P., Bombonati, A., Waldman, S.A., \& Pitari, GM. (2011). Phosphorylation of vasodilator-stimulated phosphoprotein Ser239 suppresses filopodia and invadopodia in colon cancer. Int J Cancer, (Epub ahead of printing), PMID 21702043 


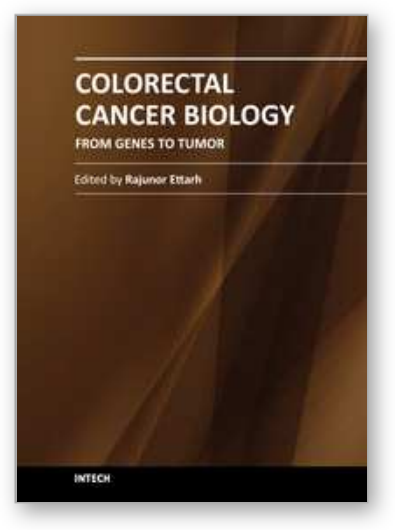

\author{
Colorectal Cancer Biology - From Genes to Tumor \\ Edited by Dr. Rajunor Ettarh
}

ISBN 978-953-51-0062-1

Hard cover, 446 pages

Publisher InTech

Published online 10, February, 2012

Published in print edition February, 2012

Colorectal cancer is a common disease, affecting millions worldwide and represents a global health problem. Effective therapeutic solutions and control measures for the disease will come from the collective research efforts of clinicians and scientists worldwide. This book presents the current status of the strides being made to understand the fundamental scientific basis of colorectal cancer. It provides contributions from scientists, clinicians and investigators from 20 different countries. The four sections of this volume examine the evidence and data in relation to genes and various polymorphisms, tumor microenvironment and infections associated with colorectal cancer. An increasingly better appreciation of the complex inter-connected basic biology of colorectal cancer will translate into effective measures for management and treatment of the disease. Research scientists and investigators as well as clinicians searching for a good understanding of the disease will find this book useful.

\title{
How to reference
}

In order to correctly reference this scholarly work, feel free to copy and paste the following:

Mehboob Ali and Giovanni M. Pitari (2012). Emergent Concepts from the Intestinal Guanylyl Cyclase C Pathway, Colorectal Cancer Biology - From Genes to Tumor, Dr. Rajunor Ettarh (Ed.), ISBN: 978-953-510062-1, InTech, Available from: http://www.intechopen.com/books/colorectal-cancer-biology-from-genes-totumor/emergent-concepts-from-the-intestinal-guanylyl-cyclase-c-pathway

\section{INTECH}

open science | open minds

\section{InTech Europe}

University Campus STeP Ri

Slavka Krautzeka 83/A

51000 Rijeka, Croatia

Phone: +385 (51) 770447

Fax: +385 (51) 686166

www.intechopen.com

\section{InTech China}

Unit 405, Office Block, Hotel Equatorial Shanghai

No.65, Yan An Road (West), Shanghai, 200040, China

中国上海市延安西路65号上海国际贵都大饭店办公楼 405 单元

Phone: +86-21-62489820

Fax: $+86-21-62489821$ 
(C) 2012 The Author(s). Licensee IntechOpen. This is an open access article distributed under the terms of the Creative Commons Attribution 3.0 License, which permits unrestricted use, distribution, and reproduction in any medium, provided the original work is properly cited. 